\title{
BLOATED BUSKINS: SENECA AND THE SATIRIC IDEA OF TRAGEDY
}

\section{Robert Cowan}

If satire is epic's 'evil twin', then tragedy is satire's ugly sister. ${ }^{1}$ Both epic and tragedy soar aloft in the stratosphere of the generic hierarchy, viewed humbly and from a distance by satire's pedestrian muse, who at the same time scoffs at their overblown irrelevance. ${ }^{2}$ Many of the same criticisms, often framed as backhanded compliments, are cast at both genres by their poor relation, but there are also distinctions. Epic, even if cloistered in an ivory tower, is constructed as sharing the impossible purity of that ivory, the better for its lofty and noble themes to be befouled, debased and perverted in the distorting mirror held up by its evil twin. ${ }^{3}$ Tragedy, however, is itself a perversion, ethically and aesthetically, a mishmash of vice and excess which is a natural target for satire, the self-appointed social policeman, but which also bears an uncomfortable resemblance to satire's own nature. Much work has been done in recent years on satire's engagement with and tendentious construction of tragedy, but very little on tragedy's reciprocal engagement with satire. ${ }^{4}$ The latter will be the focus of this article, approached from two, closely-related angles.

First, I shall explore the ways in which Senecan tragedy can be seen to engage creatively with the 'idea' of tragedy-however stereotyped and distorted, or rather because it is stereotyped and distorted-which satire constructs. Such an approach must of course situate itself in the growing body of work on generic

I am grateful to Chris Trinacty and Mike Sampson for the kind invitation to contribute to this special issue of Ramus, and their subsequent patience, advice and support. Between submission and revision, an abbreviated version was delivered to the Classical Association of New South Wales at CCANESA, the University of Sydney. My thanks to the audience, esp. Roger Pitcher and Andrew Miles, to the editors and to Ramus' anonymous reader for suggestions which have improved the article. My thoughts on Senecan tragedy have also been enriched by discussions with my University of Sydney students for Latin Imperial Poetry (2015) and Tragedy and Society in Greece and Rome (2016), to whom this article is dedicated.

1. Morgan (2004), 8: 'Couching the anti-literature of satire in the metre of heroes clarified the status of Lucilius' genre as the "evil twin" of respectable poetry, epic above all.' Bartsch (2015), 201f.: 'Persius ... repeatedly depicts the body of poetry as the blemished body of a human. In satire 1, for example, we meet in short succession both "the veiny book of Accius" (1.76) and "Pacuvius and his warty Antiope" (1.77-79).'

2. See also Littlewood in this volume on tragedy and epic's sublime ambitions, briefly contrasted with satire.

3. On satire and epic, see esp. Winkler (1989); Schmitz (2000), esp. 208-21; Morgan (2004); Connors (2005); Jones (2007), 95-116; Cowan (2011).

4. On satire and tragedy: Smith (1989); Cowan (2009); Cowan (2013), 119-21; Keane (2003); Keane (2006), 13-41. Littlewood (2007) includes much discussion of satiric engagement with epic and tragedy as a pair. 


\section{ROBERT COWAN}

self-consciousness and self-awareness, not only among Senecan characters, but in the plays' very texture. My debt to Gregory A. Staley's study Seneca and the Idea of Tragedy extends far beyond the opportunity for a pseudo-satiric deformation of its title. ${ }^{5}$ The other important springboard for conceiving that it is even possible for tragedy itself to engage with the satiric idea of tragedy is Stephen Hinds's notion of 'essential epic'. ${ }^{6}$ This offers the crucial insight that generically elevated genres can themselves engage with the essentializing stereotypes of their own generic norms which are more commonly associated with lower genres' project of self-definition by contrast. If Roman epic can show awareness of elegy's cliché that it is 'all war, all male, all the time', ${ }^{7}$ then it is worth exploring whether tragedy engages in any way with satire's caricature of it as swollen, grandiose and monstrous.

The second angle of approach is to look for the presence, not of satire's idea of tragedy, but of satire itself (or at least an idea of satire) within the fabric of Senecan tragedy. Again, there is a strong and growing body of scholarship on the presence and manipulation of 'alien' generic elements such as epic and elegy in the tragedies, but only one-solid but circumscribed-examination of their use of satire. ${ }^{8}$ I shall argue that Seneca embeds satiric motifs and even satirist-figures within the tragedies, often with a degree of polemic which simultaneously attacks satire and aligns itself with satire's own propensity for self-attack. Yet he also incorporates and assimilates satiric elements as a means of underlining the contemporary relevance of his mythological subject-matter, thus rejecting one aspect of the satiric idea of tragedy, that it has nothing to do with 'real life'. This assimilation is facilitated by an unexpected parallelism between satire and tragedy, in theme, form and worldview, a parallelism which draws together, not only satire and actual tragedy, but satire and the satiric idea of tragedy.

\section{Swollen Cheeks and Gaping Mouths: The Satiric Idea of Tragedy}

Any generalization about satire's construction of tragedy will inevitably be something of an oversimplification. No genre was more aware than satire of the weight of its own tradition and more engaged in reworking that tradition's constituent parts. Yet, by the same token, in no genre was each practitioner more overtly and explicitly concerned with carving their own distinctive place

5. In addition to Staley (2010), important contributions include Opelt (1972); Mazzoli (1997); Mazzoli (2014b); and Schiesaro (2003). The self-awareness of Senecan characters is a major motif of much recent criticism, but see esp. Fitch and McElduff (2002); Schiesaro (2003); Littlewood (2004).

6. Hinds (2000).

7. Hinds (2000), 226.

8. Satire: Coffey (1996), 81-86. For other genres, see nn. 83-86 below. 


\section{BLOATED BUSKINS}

in the tradition and differentiating themselves from their predecessors. ${ }^{9}$ This interplay of tradition and innovation extends to each satirist's treatment of other genres. Or, rather, their treatment of other genres, as a strategy of self-definition through parallel and contrast, forms part of their wider agenda of aemulatio vis-à-vis their predecessors. ${ }^{10}$ This is not to deny any specificity in, for example, Lucilius' criticisms of Pacuvius and Accius, even if we are more sceptical about the existence of 'Pupius' lamentable tragedies' or the anonymous author of the huge Telephus and the unfinished Orestes. ${ }^{11}$ However, the dominant strand within the satiric tradition, and the one which is of most relevance to this argument, is the polemical construction of a generalized idea of tragedy, of which even the individual poets and plays, real or invented, that are held up for ridicule can be seen as at least partly emblematic.

Such an idea of tragedy is itself of course subject to change and variation. The changing 'realities' of literary and theatrical culture are unquestionably relevant, and Lucilius' response to fabulae staged at second-century BCE ludi scaenici is likely to show differences from Persius' emphasis on Neronian private reading and Juvenal's on Trajanic recitation, though even here it is striking that Lucilius' attack on Pacuvius centres on what he 'writes' (scribitis) rather than on what is performed (Lucil. fr. 587 Marx). Nevertheless, there remains a marked consistency in the idea of tragedy constructed by verse satura and its close relation, skoptic epigram. I shall largely leave Menippean satire to one side, owing partly to the paucity of evidence, partly to the fact that what evidence there is tends to point to a rather different relationship. ${ }^{12}$ As with so many aspects of Varro's Menippeae, the evidence about their engagement with tragedy is moderately extensive but frustratingly unenlightening. Despite surviving titles such as Aiax Stramenticus, Eumenides and Oedipothyestes, references to Medea and Pelias, Agamemnon and buskins, Ennius and Pacuvius, Amphion and even a quotation from Ennius' Medea Exsul, no remotely clear picture of a construction of tragedy emerges. ${ }^{13}$

9. Hooley (2007), 11: 'Satire's reiterated geneses, born again in Horace, Persius, and Juvenal, are inherently critical acts, reading-down forebears as they refashion something else in explicitly critical terms; criticism and creation fused.' Most surveys of the genre (e.g. Knoche [1957], Witke [1970], Coffey [1976], Braund [1992], Morgan [2005], Hooley [2007]) include discussion of each satirist's engagement with his predecessors and with the satiric tradition as a whole, but for a particularly provocative reading see Freudenburg (2001). For the various binary relationships, see esp. Fiske (1920) on Lucilius and Horace; Tzounakas (2005) on Lucilius (and Horace) and Persius; Hooley (1997) on Horace and Persius; Anderson (1961) on Horace and Juvenal.

10. On satire and other genres (though with very little on tragedy), see esp. Jones (2007), 95-132.

11. Pacuvius: Lucil. fr. 587 Marx; Accius: fr. 794 Marx; lacrimosa poemata Pupi: Hor. Epist. 1.1.67; Telephus and Orestes: Juv. 1.4-6.

12. On literary criticism and parody in Menippean satire: Courtney (1962); Coffey (1976), 161f.; Relihan (1993), 25-28, 59-65; O'Gorman (2005).

13. Medea and Pelias: Marcipor frr. 284f. Astbury; Agamemnon and buskins: Virgula diuina fr.

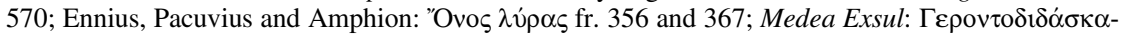
$\lambda \mathrm{o} \varsigma$ fr. 189. For suggestions on what can be made of these fragments, see the various volumes of Cèbe (1972-98), ad locc. 


\section{ROBERT COWAN}

The sole completely extant example of Menippean satire in Latin before Late Antiquity is of course Seneca's own Apocolocyntosis. This work is particularly valuable for our argument in that it demonstrates not only Seneca's awareness of but also his practical competence with many key satiric motifs and techniques, such as the focus on the grotesque body and the deliberate rejection of structural and tonal order and harmony. ${ }^{14}$ Moreover, it shows a direct engagement, not only with tragedy, but with Seneca's own tragedy, specifically the $H F$, when Jupiter sends Hercules to deal with Claudius, a monster to surpass other monsters. In response to Claudius' clowning, Hercules literally 'becomes tragic' (tragicus fit, 7.1) and blasts the dead princeps with some very Senecan trimeters (7.2). The lacuna between the opening of Claudius' conciliatory response (7.4-5) and the fait accompli of Hercules' now-established sponsorship of him (8.1) may have contained material relevant to the issue. However, it seems likely that the existing picture is a representative one and that, although the trimeters 'are interesting because they contain not only parody, but also self-parody', it is the sort of parody whose effect is produced by means of the parodied genre rather than being aimed at it. ${ }^{15}$ 'All the features of Hercules tragicus are here. The parody results from the situation he is put in, and the situation he describes: the style suits a superman confronting a monster, not a coward bullying a defenceless paralytic.' ${ }^{16}$ Seneca not only refrains from debasing tragedy here, but the effect in large measure depends on maintaining sufficient elevation for the incongruity of context to be felt. Of course, verse satire too exploits this technique on occasion, but it also regularly aims its polemical ridicule at tragedy itself. On the existing evidence, the Apocolocyntosis and perhaps Menippean satire in general seems not to have done this, so it is on verse satire that we shall focus for the satiric idea of tragedy.

As with almost everything else about Lucilius, it is hard to reconstruct in any detail his treatment of tragedy owing to both his poetry's fragmentary survival and its distortion through the lens of its later (mainly satiric) reception. ${ }^{17}$ The second issue is less problematic for the purposes of this argument, since it is precisely that later construction, the idea of Lucilius' idea of tragedy, with which we would expect Seneca to engage, rather than a more authentic, historicizing version. Even so, there is a limit to how much even of that idea of an idea can be reconstructed. Parallels can be drawn with his engagement with epic (and the idea of epic), tempered by a sense of his more specific contributions to literary criticism. ${ }^{18}$ Regarding his engagement with tragedy per se, his criticism of Pacuvius is particularly significant:

14. Body: Braund and James (1998); disorder: Robinson (2005).

15. Courtney (1962), 92.

16. Eden (1984), 93.

17. On Lucilius and tragedy: Puelma Piwonka (1949), 117f.; Krenkel (1957-8); Ronconi (1963); Bramble (1974) 174 n.1; Schmidt (1977); Manuwald (2001b); Faller (2002); Mondin (2002-3); Boyle (2006), index s.v. 'Lucilius'; Goh (2015), 111-13.

18. Lucilius and epic: Christes (2001). Lucilius and literary criticism: Krenkel (1957-8); Ronconi (1963); Coffey (1976), 52-54; Koster (2001). 


\section{BLOATED BUSKINS}

nisi portenta anguisque uolucris ac pinnatos scribitis

(Lucil. fr. 587 Marx)

[nothing] but monsters and flying, winged serpents do you write

Even in this single line, many of the key aspects of the satiric idea of tragedy may be seen in embryo. The totalizing force of < nihil > nisi establishes this description as emblematic of Pacuvius' entire tragic output and potentially of tragedy as a whole. The latter notion is reinforced by the plural verb, whether plural for singular, making Pacuvius legion, or a true plural covering all tragic poets. ${ }^{19}$ Its defining characteristics are the monstrous and the fantastic, for which the winged serpents which carried Medea home to Colchis in the Medus stand as a synecdoche. Within this vivid image are contained in embryo at least two of the three main, interrelated charges regularly cast by satire at tragedy, that its form and content are perverted and monstrous, and that this fantastical quality renders it irrelevant to satire's own sphere of 'real life'. A foreshadowing of the other accusation, that tragedy is excessive in size, style and subject-matter, might also be more faintly detected in the image of the enormous serpents flying high in grandiose would-be sublimity.

Horace's Sermones make no explicit statements about tragedy. Though his extensive discussion of the genre in the Ars Poetica has been shown to impact upon Senecan tragedy, and that work as a whole has even been categorized as satire, the complexity of its form, scope and purpose mean that it cannot usefully be taken as expressing a characteristically satiric idea of tragedy. ${ }^{20}$ In the Sermones themselves, the same stereotypes of tragedy as lofty, grandiose, excessive, transgressive, and irrelevant, all in polar contradistinction from Horace's own walking Muse and all to be rejected, are pervasive, but implicit. They underlie the bathetic incongruity of referring to the miser Ummidius' murderous mistress as the bravest of the daughters of Tyndareus, when 'highbrow tragedy is replayed as a low-budget soap-opera' and the generically loaded departure of the tragic Varius Rufus from the satiric expedition to Tarentum. ${ }^{21}$ They are more prominent when, also in $S .1 .5$, the scurra Sarmentus says his sparring partner Messius has no need for buskins, so that ' $[\mathrm{b}] \mathrm{y}$ rejecting tragic boots... Horace gives a slap in

19. The deracinated line (Nonius only cites it for the gender of anguis) could also mean 'unless you write about...', which suggests an apodosis something like 'you are not writing tragedy', and would have the same overall effect.

20. AP and Seneca: Rosati (1995); and satire: Seeck (1995); and tragedy: esp. Brink (1971), Aricò (1983), Martina (1993).

21. at hunc liberta securi / diuisit medium, fortissima Tyndaridarum ('But him a freedwoman split in the middle with an axe, the bravest of the daughters of Tyndareus', Hor. S. 1.1.99f.), with Mader (2014a), 432; flentibus hinc Varius discedit maestus amicis ('From here Varius left, mournful, while his friends wept', 1.5.93); 'Varius leaves his friends wearing a tragic mask', Gowers (1994), 65 n.56 (cf. Gowers [2012], 210 ad loc.) 


\section{ROBERT COWAN}

the face to high poetry. ${ }^{22}$ Less overtly polemical, but with the same underlying conception of the tragic, Stertinius uses the tragic exempla of Orestes and Ajax to emblematize madness, carefully marking them as specifically tragic by close evocation of their depiction in Euripides' Orestes, Sophocles' Ajax and probably related Ennian or Pacuvian tragedies. ${ }^{23}$ Throughout the Sermones, Horace can be seen to be subtly evoking an idea of tragedy which was probably already present in Lucilius, which was a satiric extension of critical discourse in other genres, and which was more fully and explicitly articulated in later satire.

For it is in the later, or in one case possibly contemporaneous, satires of Persius and Juvenal, and the satiric epigrams of Martial, that we find the most developed satiric idea of tragedy, a matter of chronology to whose methodological issues we shall return in section 2 below. We have glanced at Persius' gross physicalization of Accius' and Pacuvius' tragedies in Satire 1 (n.1 above) but the most extensive and significant construction of tragedy (and epic) appears at the opening of his fifth satire:

uatibus hic mos est, centum sibi poscere uoces, centum ora et linguas optare in carmina centum, fabula seu maesto ponatur hianda tragoedo, uolnera seu Parthi ducentis ab inguine ferrum. 'quorsum haec? aut quantas robusti carminis offas ingeris, ut par sit centeno gutture niti? grande locuturi nebulas Helicone legunto, si quibus aut Procnes aut si quibus olla Thyestae feruebit saepe insulso cenanda Glyconi. tu neque anhelanti, coquitur dum massa camino, folle premis uentos nec clauso murmure raucus nescio quid tecum graue cornicaris inepte nec scloppo tumidas intendis rumpere buccas. uerba togae sequeris iunctura callidus acri, ore teres modico, pallentis radere mores doctus et ingenuo culpam defigere ludo. hinc trahe quae dicis mensasque relinque Mycenis cum capite et pedibus plebeiaque prandia noris.' non equidem hoc studeo, pullatis ut mihi nugis pagina turgescat dare pondus idonea fumo.

(Pers. 5.1-20)

22. nil illi larua aut tragicis opus esse cothurnis ('that he had no need of a ghost of tragic buskins', 1.5.64), with Gowers (1994), 59. Cf. Gowers (2012), 202 ad loc. on how 'the rejection of tragic gear... suggests a programmatic preference for comedy.'

23. Muecke (1993), 153 ad 2.3.187-223: 'Like Orestes, Ajax is another famous madman of tragedy known on the Roman stage.' Of course, Stertinius' Stoic point is that Orestes was as mad when he killed his mother as when afterwards pursued by the Furies, and Agamemnon as mad as Ajax, but the association of tragedy and madness remains. 


\section{BLOATED BUSKINS}

Bards have this custom, to demand for themselves a hundred voices, to wish for a hundred mouths and a hundred tongues for their songs, whether a play is being presented to be gaped by a mournful tragic actor,

or the wounds of a Parthian drawing a spear from his groin.

'What direction is this going? Or how big are the hunks of tough song

you're piling up, that it's appropriate to toil on them with a hundredfold gullet?

Let those who are going to say something grand gather clouds from Helicon,

if there are any for whom either Procne's or Thyestes' pot

will boil, to be dined on by the ever-tasteless Glyco.

You neither, while the ore is smelted in the furnace, drive with puffing bellows the winds nor, hoarse with a choked roar,

do you caw to yourself something weighty absurdly

nor strive to burst your swollen cheeks with a pop.

You aim at the toga's words, expert with the acute juxtaposition, smooth with a moderate mouth, skilled at shaving sallow morals and at transfixing a vice with free-born jest.

Drag away from here what you say and abandon to Mycenae the feasts

with head and feet, and get to know the people's brunch.'

For my part, I have no zeal for this, that with trifles dressed in mourning

my page should swell, suited to giving weight to smoke.

It is far beyond the scope of this article to separate the layers of irony in this passage and analyse its complex construction of Persius' idea of his own satire. ${ }^{24}$ Yet it is worth quoting in full since it presents in particularly concentrated form-appropriately enough for the provider of aliquid decoctius ('something more boiled down' 1.125) —almost all of the key features of the satiric idea of tragedy, and does so in a quintessentially satiric way. Tragedy and epic are interwoven throughout, or rather there is constant slippage between them, with features characteristic of one genre (the epic many-mouths motif, tragic cannibalistic feasts) being assigned to both. Yet it is tragedy which emerges as the main focus, as epic's hundred mouths are morphed into the tragic gape and a passing reference to a Parthian epic warrior is engulfed by pot-loads of Thyestean stew. Overarching is the sense of tragedy's distance from and irrelevance to 'real life', the one aspect of the satiric idea of tragedy which we shall see Seneca rejecting.

24. On the passage, see esp. Bramble (1974), 2-12; Gowers (1993), 180-88; Hooley (1997), 64-80; Zietsman (2004); Bartsch (2015), 25-34. 


\section{ROBERT COWAN}

Yet this distance is expressed through images of excessive and transgressive elevation and grandiosity of utterance and subject-matter (centum ora, hianda, grande locuturi, nescio quid grande... cornicaris, contrasting with ore... modico) with particular emphasis on swelling (tumidas...buccas, turgescat). With exceptional wit, Persius combines the gaping mouth which belongs simultaneously to the tragic mask and the bombastic tragedian with the ravenous maw of the cannibalistic tragic characters. The monstrosity of tragedy's material and its mode are magnified by having each trope the other.

Juvenal's engagement with tragedy is complicated by the issue of his status as a 'tragic satirist', a notion particularly prominent in (English) Augustan satire, but still a common critical motif. ${ }^{25}$ However, this issue is not merely beyond the scope of the present argument, but of only tangential relevance. Whether or not-or rather in whatever complex ways-Juvenal was aligning his satire with an idea of tragedy, it remained largely the familiar satiric idea of tragedy which he employed, keeping it as a more-or-less fixed point and shifting instead the orientation of his own generic self-definition in relation to it. Moreover, since Juvenal long postdates Seneca (I shall return to the problems of the influence of T.S. Eliot upon Shakespeare in section 2 below), the latter could not be engaging with any innovative variations on the satiric idea of tragedy which the former might be argued to have introduced. Rather, both Seneca and Juvenal are engaging in their different ways with the pre-existing, broader idea, and it is for this that the latter can, with due caution, be used as evidence. We have already glanced at the famous opening of Juvenal 1, where tragic recitationes are lumped with epic ones as equally tedious, equally irrelevant to the 'real world' which makes it 'hard not to write satire' (difficile ... saturam non scribere, 1.30), and-perhaps most significant for the present argumentequally oversized, be it the 'enormous' (ingens) Telephus (1.4f.) or the Orestes which is not just huge but explicitly too huge, overrunning boundaries concretized by the margins and verso of the papyrus (1.5f.).

Yet it is another famous passage, near the end of the lengthy diatribe against women (or at least marriage) that is the sixth satire, which is the most important of Juvenal's pronouncements about tragedy:

fingimus haec altum satura sumente coturnum scilicet, et finem egressi legemque priorum grande Sophocleo carmen bacchamur hiatu, montibus ignotum Rutulis caeloque Latino? nos utinam uani. sed clamat Pontia 'feci, confiteor, puerisque meis aconita paraui, quae deprensa patent; facinus tamen ipsa peregi.'

25. On the Augustan idea: Weber (1981). In modern criticism: Anderson (1962); Schmitz (2000), 43-50; Keane (2006), 13-41; Ferriss-Hill (2015), 20-22. 


\section{BLOATED BUSKINS}

tune duos una, saeuissima uipera, cena?

tune duos? 'septem, si septem forte fuissent.'

credamus tragicis quidquid de Colchide torua

dicitur et Procne; nil contra conor.

(Juv. 6.634-44)

I'm inventing these things, as my satire puts on a lofty buskin,

I suppose, and after going beyond the legal boundary of my predecessors

with Sophoclean gape I howl like a bacchant a grand song

unknown to the Rutulian mountains and the Latian sky?

If only I were speaking idly. But Pontia shouts, 'I did it,

I confess, and I prepared aconite for my boys,

which was detected and exposed; nevertheless I myself carried out the crime.'

Did you kill two with one, cruellest viper, dinner?

Did you kill two? 'Seven, if seven there had happened to be.'

Let us believe the tragedians, whatever about the fierce Colchian woman

is said and about Procne; I'll make no attempt to contradict them.

Again, this is a much-discussed passage and one, in combination with his claim that the cannibalism of the Ombi was 'more serious/weighty than all buskins' (cunctis grauiora coturnis, 15.29), which is fundamental to Juvenal's selfpositioning as outdoing rather than contrasting with tragedy. ${ }^{26}$ This peculiarly Juvenalian move will be relevant to my subsequent discussion (section 5 below) about the affinities of tragedy and satire, but the main interest of this passage is its further reinforcement of the key motifs of the satiric idea of tragedy. Indeed, in order to buttress his main innovation, Juvenal even projects the classic satiric notion of tragedy's unreality and irrelevance onto his interlocutor (fingimus...scilicet). Grandeur and elevation (altum...coturnum, grande... carmen) are present, already with the hint of the excess which will transform them into grandiosity and bombast. This transgressive quality is further suggested by finem egressi, referring primarily, of course, to the transgression of satiric boundaries into tragic territory, but inevitably hinting at the way that such tragedy by its nature (and hence tragic satire) transgresses all boundaries. Shared with Persius is the image of the gaping tragic mask, a physical image evoking stylistic bombast, but here with the added

26. Anderson (1962), 152f.; Morford (1972); Schmitz (2000), 43-50; Cucchiarelli (2001), 204f.; Keane (2003), 265-69; Cowan (2013), 120f; Watson and Watson (2014), 275-77; Ferriss-Hill (2015), 20-22. Powell (1999), 317-19, makes the important point that, whatever else Juvenal is doing, he is not adopting a more elevated stylistic register. 


\section{ROBERT COWAN}

psychological facet, not of cannibalistic gluttony, but of tragic Dionysiac frenzy (bacchamur). ${ }^{27}$

Finally, important illustrations of the satiric idea of tragedy are to be found among the epigrams of Martial. ${ }^{28}$ Before examining them, a brief justification should be offered for including him among the writers of satire. ${ }^{29}$ Skoptic epigram in general, and especially that of Martial, has a great deal in common with satura: its self-conscious lowness of generic status, reflected in explicit statements, mundane, sexual and scatological subject-matter, diction even less elevated and even more obscene. Yet there are also differences, several of which are relevant to its oppositional construction of tragedy and other higher genres. Epigram both constructs and deconstructs its smallness of scale, its own ephemerality, and its status as mere fun or entertainment (ludus/lusus). ${ }^{30}$ Although it shares none of these features with satire, it takes advantage of the fact that the polar antitheses of these qualities are facets of the tragic idea which satire sets in opposition to its own features. Epigrammatic smallness of scale in all dimensions stands in even more pointed antithesis with swollen, grandiose tragedy than the merely altitudinous lowness of satire. Satire's selfrepresentation has many facets but they rarely, if ever, include fun, entertainment or triviality, so that its assertion of tragedy's irrelevance falls short of the total inversion whereby Martial claims that 'although epigram is ... labelled a lusus

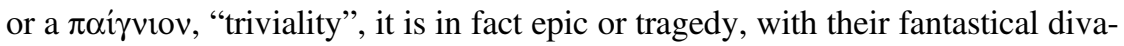
gations on tralatician or recondite themes, which are in fact trivial.' ${ }^{31}$ Whether we attribute this situation to happy coincidence or skilled opportunism on Martial's part, the result is that the latter's idea of tragedy precisely corresponds to the satiric idea, and indeed can be seen as drawing on earlier instantiations of that idea.

Like the satirists, Martial's engagements with tragedy tend to link it closely with epic, though he sometimes extends the target to include all mythological poetry, including on one occasion with a para prosdokian ('contrary to

27. Cucchiarelli (2001), 204 n. 64: 'La scelta lessicale di hiatus, a prescindere dall'ovvio significato stilistico, forse vuole visualizzare la maschera dionisiaco-tragico, atteggiata abitualmente in un enorme grido' (The choice of the word hiatus, leaving aside the obvious stylistic significance, is perhaps intended to conjure the image of the Dionysiac tragic mask, whose usual expression is an enormous shout); he further suggests (more tenuously) that the Rutulian hills might evoke maenads characteristically roaming the mountains.

28. On Martial and tragedy in general: Citroni (1968); Sullivan (1987b), 178-80; Sergi (1989); Spisak (1994), 303-05. On Martial and Attic tragedy: Mindt (2013), 529-32.

29. For Martial as a fully-fledged satirist, see esp. Sullivan (1987a). Many scholars (e.g. Mendell [1922]) write more vaguely of his 'satiric epigram' as an alternative term for skoptic, but without situating him in the Lucilian (as opposed to the Lucillian) tradition.

30. On Martial's self-representation see esp. Sullivan (1991), 56-77; Fitzgerald (2007); Neger (2012). On 'Martial's branding of epigram as both memorialising and ephemeral': Rimell (2008), 51-93, quoting from 63.

31. Watson (2003a), 4. Persius' description of tragic themes as 'dark-robed nonsense' (pullatis... nugis, 5.19f.) does paradoxically brand an elevated genre as a trifle, but without the defensive implication that others would usually so describe satire. 


\section{BLOATED BUSKINS}

expectation') effect extreme, even for Martial, Callimachus' Aetia. ${ }^{32}$ Yet tragedy always has a distinct identity and Martial shares with-perhaps draws fromPersius the conflation of stylistic and psychological metaphor and corporeal subject-matter. In the opening couplet of 10.4, devoted to tragic themes, Martial develops Persius' already vivid image of 'trifles in dark robes' (pullatis...nugis, 5.19) into the 'dark Thyestes' (caligantem...Thyesten, 10.4.1), simultaneously evoking the premature night caused by the sun's flight, Thyestes' mental blindness, and the gloominess and perhaps recondite obscurity of the

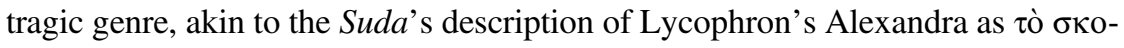
$\tau \varepsilon$ เvòv $\pi$ oinj $\mu \alpha$ ('the murky poem'). ${ }^{33}$ The addressee, Mamurra, reads nothing but monstra (10.4.2), physically unnatural creatures like Scylla and ethically transgressive freaks like Medea, all populating a genre wilfully violating canons of proportion and decorum. ${ }^{34}$ The schoolteacher who dictates tragedies to his unwilling pupils is 'swollen' (tumidus, 8.3.15) by his own arrogance and pomposity but also by the bombast of his chosen genre.

Martial's development of the satiric idea of tragedy is perhaps most clearly and fully demonstrated in his defence of epigram to Flaccus:

nescit, crede mihi, quid sint epigrammata, Flacce, qui tantum lusus ista iocosque uocat.

ille magis ludit, qui scribit prandia saeui Tereos, aut cenam, crude Thyesta, tuam, aut puero liquidas aptantem Daedalon alas, pascentem Siculas aut Polyphemon ouis. a nostris procul est omnis uesica libellis, Musa nec insano syrmate nostra tumet.

'illa tamen laudant omnes, mirantur, adorant.' confiteor: laudant illa, sed ista legunt.

(Mart. 4.49)

He doesn't know, believe me, Flaccus, what epigrams are, the man who calls those poems only jests and jokes.

He jests more, who writes about the lunch of fierce Tereus, or your dinner, Thyestes savage with indigestion,

32. Mart. 10.4; Watson and Watson (2003), 99: '[Callimachus' Aetia] normally symbolises the "slender" style of poetry as opposed to the trite and inflated genus of epic but here is associated... with the unreal themes of elevated poetry.' Cf. Citroni (1968), 280; Sergi (1989); Spisak (1994), 344f.; Mindt (2013), 547-49; Cowan (2014), 350-52. Hinds (2007), 136-39, also argues for an indirect engagement with Ovid's Metamorphoses here and in 4.49 .

33. $O L D$ s.v. caligo $^{2} 1$ 'To... be shrouded in darkness'; 3 'To... be blinded in judgment'. Curiously, Mart. 10.4.1 is quoted under 2c 'to see dimly (from external causes)'. 'The Alexandra is

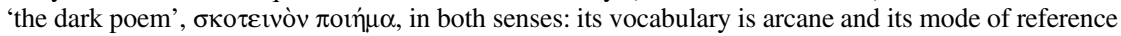
is veiled; and it is full of blood, death, tombs, and laments.' Hornblower (2015), 1.

34. On Senecan monstra: Staley (2010), 96-120, and section 3 below. 


\section{ROBERT COWAN}

or Daedalus fitting melting wings to his boy, or Polyphemus pasturing Sicilian sheep.

Far from my little books is all swollenness, nor does my Muse swell with frenzied tragic robe.

'Those poems, nevertheless, everyone praises, admires, venerates.' I admit it: they praise those, but it is these that they read.

The defensive deflection of the charge of triviality made against epigram on to higher genres is subtly performed. ${ }^{35}$ Though no mention is made of monstra, the paradigmatic figures are carefully chosen to embody grotesque and fantastical transgression, either of socio-ethical norms through cannibalism, the laws of physics through flight, or of physiology through monophthalmic gigantism. Martial has his cake and eats it by reducing the tragic themes to the level of nugae through the application of low diction, notably prandia, to lofty subjectmatter. Again a multivalent adjective is applied to Thyestes, who is crudus physically, through indigestion caused by eating his sons, ethically, in his savagery, and generically, as the subject of unpolished poetry. ${ }^{36}$ Martial's own poetry, lightly personified as his Muse to facilitate the slippage between the critical, psychological and physical, does not 'swell' (tumet) by putting on a tragic costume, the syrma, which is itself characterized as insanus. Moreno Soldevila insists that 'insanus is sometimes applied to intemperate speech... although here it clearly refers to the extravagant cruelty of tragic plots', but of course we need not choose, since it is precisely the satiric technique to conflate criticism of form and content. ${ }^{37}$ More sensitively she notes that tumet 'alludes both to arrogance... and affected, grandiloquent language', though here too we might be tempted to add a physical dimension, recalling the bloated indigestion of Thyestes. In both message and medium, and especially in his blending of the two, Martial follows and thus represents the satiric technique of constructing an idea of tragedy.

The satiric idea of tragedy — or at least a simplified version of it, not dissimilar to its own essentializing of other genres, so that we might think in terms of an idea of the satiric idea of tragedy — can be briefly summarized as follows. Tragedy is grand, both elevated in altitude and enormous in other dimensions. Yet its grandeur is excessive and transgressive, always 'more', in comparison with other genres, with itself, and with all boundaries of decorum and normality. This excessive size is particularized into specific features such as swollenness, which slips between physical distension, psychological arrogance or anger, and aesthetic bombast. It also renders tragedy monstrous, because of its subject matter and its decorum-violating form. All of these qualities are primarily employed to

35. On this epigram, see Citroni (1968), 274f.; Spisak (1994), 303f.; Boyle (1995), 85-87,

36. OLD s.v. crudus 3b 'dyspeptic', 7 'fierce, wild, savage', 2e 'lacking in elegance, coarse, rude, unrefined'.

37. Moreno Soldevila (2006), 362. 


\section{BLOATED BUSKINS}

serve the argument that tragedy is divorced from real life, irrelevant and even trivial, particularly in contrast with satire (or epigram) itself. We shall see Seneca appropriating and exploiting all of these aspects except the last, irrelevance, which he refutes in part by using a tragic idea of satire. But before we turn to justifying the claim for Seneca's use of the satiric idea of tragedy, it will be useful to shift the focus from the idea's content to reflect a little on its technique.

The slippage between the grand and the bombastic in the satiric idea of tragedy is at least in part a function of the way in which satire takes what are more widely considered the qualities of bad tragedy and makes them the qualities of all tragedy, or rather of tragedy tout court. Often these qualities are, in less polemical criticism, the vices corresponding to the virtues of good tragedy. tumor ('swollenness/bombast') in particular is repeatedly the vice into which the elevation and sublimity appropriate to lofty genres of epic, tragedy and oratory can all too easily tip. In Greek, the distinction is so fine that it is often expressed by the same word, ő $\gamma \kappa \varsigma_{\zeta}$, whose positive sense of 'grandeur' (e.g. Arist. Po. 1459 b28) and pejorative one of 'bombast' (e.g. Plu. Mor. 2.79b) can only be differentiated through context. Latin authors reserve tumor and tumidus for negative judgements (Hor. AP 94 is an intriguing exception). Quintilian includes it among the 'vices very close to virtues' (proxima uirtutibus uitia) which superficial students of oratory develop, some of them becoming 'bombastic instead of elevated' (pro grandibus tumidi, Inst. 10.2.16) and elsewhere, conversely, insists that the speeches of the good orator who observes the golden mean will be, among other things, 'elevated not bombastic' (grandia non tumida, 12.10.80).

Satire, by contrast, does not acknowledge that the virtues even exist in tragedy. It is just conceivable that some of satire's attacks on tragedy could be construed as targeted criticisms of specific tragedians qua bad tragedians, including an implicit contrast with actual or hypothetical good tragedians. Lucilius may be pillorying Pacuvius' portenta in contrast with the better practice of, say, Naevius or Aeschylus, Juvenal the grandiosity of the Telephus with the moderation of Accius or Euripides. Yet this is a strained argument, and the emphasis is exclusively on the negative, with not even a hint at the existence of contrasting 'good' tragedies, so that the effect on the reader is inevitably to produce the synecdochic impression that all tragedy is like this. Moreover, the criticism is not limited to contemporary degenerates, but extends to celebrated tragedians of the past. Persius' attitude toward Accius and Pacuvius might be hard to unpack, but when Juvenal writes of a 'Sophoclean gape', he is attributing overblown grandiosity to the figure whom the Romans considered the best of the tragedians. ${ }^{38}$ This aspect of the satiric idea of tragedy is important for two reasons. Firstly, it

38. Juv. 6.636 (quoted above). Mindt (2013), 530, describes Martial's references to Sophocles as follows: 'Doch gerade in der Stellvertreterrolle, die Martial Sophokles zuweist, spiegelt sich die Wertung, der communis opinio der Zeit in Rom entsprechend, Sophokles sei der beste Tragiker' (But it is precisely in the representative role that Martial assigns to Sophocles that the judgment is 


\section{ROBERT COWAN}

serves to reinforce the sense that it is indeed satire's polemical construct of the genre with which Seneca is engaging, rather than the wider critical discourse. Secondly, and more importantly, the very perversion of what other ancient critics considered stylistic virtues into vices serves to trope the perversion of ethical and political virtues, a parallelism which both satire and Senecan drama pervasively exploit.

Just as important as satire's idea about what tragedy is like and about its social function (or lack thereof) are the symbolic means it employs to express that idea. Although other techniques are employed, the dominant trope is the reification of critical metaphor. Of course, many critical metaphors are drawn from the domain of the physical, especially the corporeal, and are thus particularly susceptible of concretization. Just such a process is already well-established in the comic tradition, from the would-be winged poet Cinesias in Aristophanes' Birds to Aeschylus' fat tragedy in his Frogs, and is even manifested in less overtly humorous contexts, notably the Callimachean tradition of slender Muses and big women. ${ }^{39}$ Even Longinus more-or-less equates the physical and critical senses of örкos ('tumour/bombast') stating that they are 'bad both in bodies and in words'. ${ }^{40}$

However, in satire there is a particularly developed emphasis on the bidirectionality of the symbolic relationship between the literary and the corporeal. In a move similar to Hinds's notion of 'reversing the trope' in intertextuality, whereby for example poetic memory is a trope for cognitive memory as much as vice versa, satire's condemnation of bloated poems is a way of condemning bloated bodies just as much as the other way round. ${ }^{41}$ As Bramble puts it,

As we might expect, given the principle of correspondence between style and character, letters and Bíos ['life'], the exponent of the lower forms correlates his attitude of scorn for physical enormity with abhorrence from the grandiose and inflated in literature. ${ }^{42}$

Indeed, as Bramble's mention of character intimates, we can extend this binary relationship to the triangulation of the literary-critical and the corporeal with the third term of the ethical. Seneca himself offered one of the classic articulations of the doctrine that 'style is the man' (Ep. 114) and it is a pervasive motif in satire, from Horace's paradoxically Callimachean satirist who exhibits moderation in all things, simple food, slender poetry, temperate emotions, to one of our key

reflected, corresponding to the communis opinio of the time in Rome, that Sophocles was the best tragedian).

39. Ar. Av. 1372-1409, Ran. 939-43, Call. Aet. fr. 1.24, 1.12. Among the extensive bibliography, see esp. Wright (2012), 103-40, on Old Comedy; Hunter (2009), 10-52, on its afterlife; Asper (1997) on Callimachus.

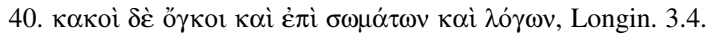

41. Hinds (1998), 10-16.

42. Bramble (1974), 158. 


\section{BLOATED BUSKINS}

examples of the satiric idea of tragedy, Persius' gaping, swollen tragedian whose cannibalism, bombast and overliving all trope each other. ${ }^{43}$

\section{Essential Tragedy and Other Methodological Issues}

Of course, it is one thing to observe that satire constructs a stereotypical idea of tragedy whose defining characteristics are swollenness, excess, grandiosity and monstrosity. It is quite another to argue that tragedy itself could acknowledge, let alone adopt and exploit, such a stereotype. A suggestive parallel may be found in epic's exploitation of the idea of epic, what Stephen Hinds has termed 'essential epic'. Hinds demonstrates that the essentialized idea of epic's generic norm as exclusively masculine and martial- 'all war, all male, all the time'-is not limited to the gesture of self-definition by contrast familiar from elegy, pastoral, lyric and other self-consciously 'lower' genres. ${ }^{44}$ Such an idea of epic does not, of course, correspond with the plot of any actual, individual epic poem. ${ }^{45}$ Yet epics themselves, just as much as the 'lower' genres which define themselves in contrast to them, react to any divergence from this supposed norm with (staged) surprise and discomfort. Starting from Ovid's characterization of Aeneid 4 as an erotic, elegiac, unepic aberration, Hinds argues that 'some element of surprise at the Aeneid's assimilation of such an erotic episode [is] encoded, albeit less luridly, within the Aeneid itself' and that 'the Tristia 2 vignette is as much a commentary on Virgil's own self-conscious play with epic norms as it is a parodic reading. ${ }^{4} 6$

The key element which I wish to draw from Hinds's argument is that a genre, be it epic or tragedy, can engage with a stereotypical, essentialized idea of its own generic norms which originates, or is at least more at home, in other genres. I use the broad term 'engage with', because the nature of the engagement which I propose tragedy has with satire's idea of tragedy is fundamentally different from that of epic with elegy's idea of epic. I do not want to present too reductive a picture of Hinds's argument, not least because he particularly stresses the Virgilian (and wider epic) practice of 'dynamic impurity', which is 'to emplot into his epic poem a continuing discussion about the otherness of the epic female ... in such a way that even the terms of reference of the debate do not remain static', an element of dynamism and dialogue which I believe is also present in tragedy's on-going interaction with satire ${ }^{47}$ However, the fundamental point is that epic takes what is (depending on one's generic and other perspective) a basically

43. On 'style is the man' in satire, see now esp. Ferriss-Hill (2015), 171-216.

44. Hinds (2000), quoting from p.226.

45. Cf. Most (2000), 30: "a genre of "tragedy" was hypostasized and conceived as though it were somehow independent of all particular instances of tragedies.'

46. Ov. Tr. 2.529-36. Hinds (2000), 232.

47. Hinds (2000), 233. 


\section{ROBERT COWAN}

neutral idea of epic generic norms (martial and masculine) and plays with its transgression of that idea. In contrast, I wish to argue that Senecan tragedy takes an unambiguously polemical and pejorative idea of tragedy's generic norms (swollen, excessive, grandiose, monstrous) and plays with its conformity to that idea.

A number of objections could still be made to the notion that Senecan tragedy engages with the satiric idea of tragedy, including two concerning how far that idea is in fact specific to satire and to tragedy. First, are we really dealing with an exclusively_or even predominantly_satiric idea of tragedy, as opposed to one shared with several other poetic genres and a range of literary and historical criticism? Comparing Hinds's 'essential epic' again, the notion of that genre as exclusively martial and masculine is not limited to elegy, but can be found in pastoral, lyric, and epistolary didactic, among others. ${ }^{48}$ Yet the particular 'surprise' upon which Hinds focuses is that expressed by epic at the inclusion of women and the erotic, the self-defining themes of elegy, so that there is a sense in which it is the incursion of an idea of elegy which epics are (notionally) resisting and hence predominantly the elegiac idea of epic with which they are engaging. ${ }^{49}$ However, tragedy's engagement with a polemical caricature of itself consists not of the enacted failure, through contamination by a specific other genre, to attain its (equivocal) essentialized ideal, but rather the achievement of a distinctly undesirable essentialized ideal. Thus it does not have that same direct relationship with satire itself (as opposed to satire's idea of tragedy) which epic has with elegy itself. Indeed much of Seneca's construction of his tragedies as swollen, transgressive and monstrous can be understood on the basis of wider characterizations of the genre, just as 'essential epic' can through pastoral and lyric. However, as noted earlier, the insistence that all tragedy, or rather-since such essentializing moves tend to elide the very notion of individual instantiations of the genreessentialized tragedy has all the flaws which other genres assign only to bad tragedy is quintessentially satiric. Since it is this flawed quality which Seneca embraces as central to his conception of his tragic style and his tragic universe, it is the satiric idea of tragedy with which he is primarily engaging.

Moving from source to target genre, we must ask how specifically it is the satiric idea of tragedy as opposed to that of other elevated genres, especially epic. This is particularly pertinent in the present case, since tragedy is so often paired and even conflated with epic in the satiric passages we have examined, and many of the same qualities of grandeur, excess, swollenness and irrelevance are applied to both. We are in the happy position that the point may be conceded

48. reges et proelia, ('kings and battles', Virg. Ecl. 6.3); quam rem cumque ferox nauibus aut equis / miles ... gesserit, ('whatever a fierce soldier achieved with ships or horses', Hor. Carm. 1.6.3); res gestae regumque ducumque et tristia bella, ('the achievements of both kings and generals and grim wars', Hor. $A P$ 73).

49. Note Hinds's (2000), 230, acknowledgment that, at Tr. 2.529-36, 'Ovid's purposes lead him to deemphasize Dido's more obvious affinities with tragedy in favor of her affinities with elegy and other "slight" genres.' 


\section{BLOATED BUSKINS}

without substantially affecting the argument, while at the same time there is enough to suggest that many of these qualities are (or can be made to 'feel') more strongly associated with tragedy than with epic. In the broadest terms, it could easily be argued that Seneca is engaging with the satiric idea of elevated genres as a whole and that, since tragedy is one of those genres and it is tragedy that he is composing, he can treat the qualities which constitute that idea as (a distorted stereotype of) 'tragic' qualities, without necessarily precluding (or even bothering) that they might also be 'epic'. The stronger argument is that these transgressive, perverted qualities better match the genre of familial, social and cosmic disruption than that of foundation, memorialization and heroic values. Or perhaps rather that, by exploiting satire's move to make the qualities of bad elevated poetry those of all elevated poetry, Seneca makes his reader feel that, while an epic which matched the satiric idea of epic would be a failure, the satiric idea of tragedy is so paradoxically in harmony with his idea of tragedy that a play in that mould, for all its flaws-nay, because of all its flaws-would be a total success.

Another substantial objection to detecting in Senecan tragedy a creative response to the satiric idea of tragedy is the fact that many of the clearest and most developed examples (including several of those discussed in section 1 above) postdate the plays themselves, even on their latest dating. ${ }^{50}$ This is, of course, certainly the case with Martial and Juvenal, and at least probable for Persius. Meaning is generated at the point of reception, intertextuality is multidirectional, there is an influence of T.S. Eliot upon Shakespeare, and of Statius on Virgil, and it is not only uncontroversial but, in itself, interesting and significant that later readers and audiences cannot approach Senecan tragedy without their experience of it being affected by the depiction of tragedy in later texts. ${ }^{51}$ Indeed, critics dismissive of Seneca often explicitly or implicitly use satiric testimony to support their views. ${ }^{52}$ Yet that is not the case which this article is trying to make. There is still an important place for directionality and even, within limits, intentionality in intertextuality and, by extension, generic self-fashioning, and it is just such a conscious engagement by Seneca with the satiric idea of tragedy for which I wish to argue. The issue of chronology must therefore be addressed, and also that of whether some of our satiric passages might be not only

50. The dating of Seneca's tragedies, both relative and absolute, is almost endlessly controversial, despite the wide acceptance of the arguments in Fitch (1981), but except for the small difference it might make if some of the plays were written after, or at about the same time as, Persius' Satires, the issue does not affect the current argument. See also Nisbet (1990). Dingel's (2009) argument that $H F$, with its probable terminus ante quem of the composition of the Apoc., was Seneca's first tragedy opens up the possibility that more of the other plays were Neronian and hence not necessarily antedating Persius.

51. The classic discussion of directionality in Graeco-Roman intertextuality (including the allusion to David Lodge's Small World) is Fowler (1997), esp. 27f.

52. 'Jokes at the expense of epic and tragedy are common in Roman satire from Lucilius to Juvenal. The serious poetry of the Silver Age was particularly irrelevant to any actual human activity, and Persius' criticisms were amply justified.' Nisbet (1963), 60. 


\section{ROBERT COWAN}

post Senecam but propter Senecam. Some scholars have suggested that Persius' depiction of tragedy as a cannibalistic feast in Satire 5 might have been a direct response to the Thyestes itself. ${ }^{53}$ Staley prefaces his chapter on monsters and monstrosities in Senecan tragedy with Martial 10.4.1f. and goes on to argue that 'it was Seneca ... who gave to Martial his label for tragedy-monstrafor Seneca's recent plays had made monstrum the leitmotif of the genre.' 54

The answers to these two interrelated objections are threefold, and also interrelated. As we have seen in section 1, even if the most fully-developed extant examples come from Persius, Martial and Juvenal, there is ample, if more fragmentary, evidence that they are part of a tradition going back to Lucilius, and indeed Staley himself, even as he is attributing the importance of monstra to Seneca, cites fr. 587 Marx on Pacuvius' portenta in a footnote. ${ }^{55}$ The scraps of this tradition can and should, as we have just seen, be situated within a wider discourse about the failings of tragedy (or at least of bad tragedy) in comedy, elegy, pastoral, oratory, literary criticism and other genres. Yet we should by no means swing to the other extreme of insisting that the flow of influence is entirely from satire to Seneca. Tragedy, the satiric idea of tragedy and tragedy's reception of the satiric idea of tragedy were none of them fixed or static. Rather we should imagine a dialogue, a dynamic process in which Seneca's engagement with tragic stereotypes in turn encouraged later satirists to shape their responses in the light of his practice. The loss of almost all Roman tragedy except Seneca's, as well as of much satire, makes it difficult to trace this dynamic process with any degree of precision. Yet, while allowing for a degree of dialogue and development, we have seen in the last section sufficient continuity in the satiric idea of tragedy to justify reading Seneca in the light of Persius, Martial and Juvenal as well as of Lucilius and Horace.

\section{Something Big: Tragedy and the Satiric Idea of Tragedy}

How then does Seneca engage with the satiric idea of tragedy? By its own lex generis ('law of the genre'), tragedy of course tends to make far fewer explicit statements about poetics than satire. ${ }^{56}$ The figure of Orpheus is used, at least in part, as a reflection on poetic art in $H F$ and Medea, but with little mention of

53. Giordano Rampioni (1983), 105: 'All'inizio della V satira, quando polemizza col genere tragico, il suo non è un riferimento generico, come si legge nei commenti, al mito di Tieste portato sulla scena da tanti tragediografi greci e latini, bensì una puntuale allusione al Tieste senecano' (At the beginning of the fifth satire, when he polemicizes against the tragic genre, it is not a general reference, as it is read in commentaries, to the myth of Thyestes put on the stage by so many Greek and Latin tragedians, but rather a precise allusion to the Senecan Thyestes)'; see also Bocchi (2004).

54. Staley (2010), 96.

55. Staley (2010), 156 n.3.

56. Cf. Wright (2010) on Euripidean references to poetics. 


\section{BLOATED BUSKINS}

elevation or excess. ${ }^{57}$ There is an intriguing passage in the second choral ode of Agamemnon. The chorus of Argive maidens urges Apollo as poet-god to come in humble Callimachean or Horatian lyric guise rather than with the ruinous grandeur of tragedy or epic: 58

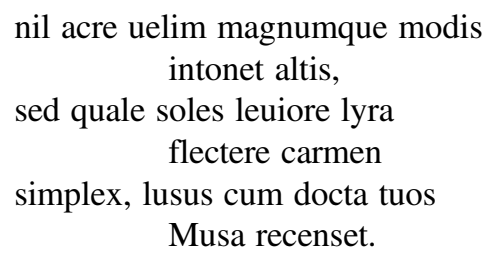

(Sen. Ag. 327-32)
Nothing strident and grand I'd want him to thunder in lofty strains,
but such a song as you are accustomed with lighter lyre to turn,
a simple one, when the learned Muse goes over your trifles.

The generic and aesthetic antithesis seems clear enough, as does its thematic corollary, characteristic of the classic kletic wish that the god come in kindly aspect: Apollo, the poeta creator, is not to sing harsh, grand, lofty epic or tragedy and is not to enact the ruinous warfare or oikos-destruction which characterizes these genres, redoubling the request to use his lyre rather than his bow (323-27). However this simple contrast is thrown into confusion by the chorus's suggestion that Apollo might sing as he did during the Titanomachy or the Gigantomachy, another conflation of poet and actor, fighting and performing possibly a paean, but with the inevitable implications of epic, for which Gigantomachy was the emblematic subject-matter. ${ }^{59}$ Whether this is a volte-face and the tragic chorus feels itself ineluctably drawn towards the lofty but destructive themes of elevated poetry, or they are in some way dividing epic from tragedy within the subset of high poetry, praying for a heroic epic rather than a catastrophic tragedy, in either case the interrelationship of tragedy, elevation and destruction is clear.

This, however, is a rare and perhaps unique case. Seneca's engagement with the satiric idea of tragedy is generally less explicit in its pronouncements about poetics. Instead he uses the metaphorical language of criticism either in its

57. On the Senecan Orpheus: Segal (1983); Bocciolini Palagi (1998); Dangel (1999); and Littlewood in this volume.

58. On Apollo in this ode: Tarrant (1976), 231-39; Motto and Clark (1988), 208; Audano (1998). On Horatian intertexts: Spika (1890), 35.

59. Ag. 333-39, with Tarrant (1976), 238 ad 340ff. (his colometry differs from Zwierlein's) on Gigantomachy and epic, esp. in recusationes. 


\section{ROBERT COWAN}

literal, usually physical sense or in its other metaphorical applications to abstract passions, crimes and sufferings. Grandiose heroes experiencing grandiose emotions symbolize grandiose tragedy. It must be admitted that, as with all metaphor, this renders the metapoetic dimension potentially elusive and difficult to prove objectively, but it is not merely Seneca's only option, faute de mieux: it is central to the means and ends of his engagement with the satiric idea of tragedy. It corresponds to what we have seen to be satire's own emphasis on the interrelationship of the aesthetic, the psychological and the physical. This is not an opportunistic exploitation of an arbitrary metaphorical field, but rather a means of exploring each of these facets through the others. For instance, the grandiosity of Hercules' pride tropes the grandiosity of his physique, and both of these trope (and are troped by) the grandiosity of the tragic genre which he embodies. ${ }^{60}$

Seneca also exploits the distinctive aspect of the satiric, in contrast to other, related ideas of tragedy, in treating the qualities of bad tragedy as those of all tragedy, or rather of essential tragedy. Seneca's idea of tragedy is bound up with excessive and distorted bodies and minds, so that the aesthetic which symbolizes and is symbolized by them is itself excessive and distorted. Indeed, it even exploits the relationship of the satiric to other ideas of tragedy, since its grandiosity — of body and mind, heroes and passions - is grandeur gone awry.

Size matters in Senecan tragedy. Everything in it is immense-passions and sufferings, heroes and monsters, ideas and plots. Juno wants Hercules to be 'driven by a great frenzy' (magno furore percitus, $H F$ 108), equal in magnitude to the 'great' hero himself (Herculis magni, 436, cf. 646f., 829) whose labours in immeasurably immense spaces involve immeasurably immense burdens (molis immensae, 'immense effort', 71; telluris...pondus immensae, 'weight of the immense earth', 424; specu, 'cave', 665; sinu, 'curve', 679; uertice, 'peak', 1208). Hector was 'great' (magnus, Tro. 237, 322, 461, 784) and 'the old man' Priam too (magni senis, 713), but now only 'misfortunes', 'grief' and 'anguish' are (magna...mala, 745; magnos luctus, 738; magnus dolor, 904, 1066). Both Neptune's bull-monster and the sea which produces it are 'huge' (ingens), the former 'a scaly beast dragging an immense tail' (ingens belua immensam trahit / squamosa partem, Pha. 1047f.), the latter 'rising into a vast mound' (consurgit ingens pontus in uastum aggerem, 1015). These bodies and these emotions correspond to the genre of Juvenal's 'grand song' (grande... carmen, 6.636), Persius' 'great...hunks of tough song' (5.5), and the 'something grand' his tragic poets are going to sing (5.7).

Yet they are not just immense, but excessively so, transgressing the boundary which divides the grandeur appropriate to the wider critical idea of tragedy from the grandiosity which characterizes the satiric idea. Comparatives regularly signal

60. Cf. Littlewood in this volume on the sublime in the play and Sampson on Hercules as 'a unique and irrepressible agent of disorder'. 


\section{BLOATED BUSKINS}

the way in which everything in the tragedies is greater than great, greater than is decorous, greater than can be readily grasped or conceptualized. ${ }^{61}$ Phaedra's lust for Hippolytus is a 'greater anguish' (maior ... dolor, Pha. 99), her crime greater than Pasiphae's or Medea's (maius est monstro nefas, 'crime greater than a monster', 143; o maius ausa matre monstrifera malum / genetrice peior, 'o woman worse than she who bore you, who have dared a greater evil than your monster-bearing mother', 688f.; Colchide nouerca maius hoc, maius malum est 'this is a greater, greater evil than the Colchian stepmother', 697). The Delphic oracle predicted to Oedipus another crime greater than parricide, a greater sin: incest (hoc me Delphicae laurus monent, / aliudque nobis maius indicunt scelus. / est maius aliquod patre mactato nefas? Oed. 16-18). ${ }^{62}$ Hercules will emerge from the underworld, as he does from every labour, 'greater' (maior, $H F$ 313) and, in his madness, he plans a 'greater war' against Eurystheus at Mycenae (maius...bellum, 996f.) All the characters of Phoenissae, haunted by the Labdacids' earlier crimes, fear greater crimes, sins and misfortunes to come $(269,272,286,353,456 f ., 531){ }^{63}$ The inconceivability of this immensity is often further underlined by the use of an indefinite, a move closely paralleled in Persius' (or Persius' Cornutus') nescio quid ... graue (5.12). Andromache employs both techniques, with added polyptoton, in describing the demand for Astyanax's death, as 'some greater ill is arising from a great one' (exoritur aliquod maius ex magno malum. Tro. 427). Again, this excess of physicality, passion, intention and action matches the excess (according to satire) of the genre which parades it, which goes 'beyond the legal boundary' (Juv. 6.635) and swells pages, cheeks and Muses (Pers. 5.19f., 13, Mart. 4.49.8).

The generic dimension of this physical, psychological, social and cosmic nexus of excessive magnitude is particularly prominent when characters take on the metapoetic and metatheatrical role of composing and staging a tragedy within the tragedy. Much excellent work has been done on Senecan metatheatre and in particular the embedded dramatist-figure. ${ }^{64}$ Juno in $H F$, Medea and even Phaedra's nurse have been shown to have this dimension to their characters. Medea in particular combines this role of dramatist with an obsession with the maius-motif, asserting that 'greater crimes are appropriate to her now she is a mother' (maiora iam me scelera post partus decent, 50) and offering herself as Jason's ally, a 'greater source of fear than any king' (his maior metus / Medea, 517f.), while the Nurse narrates that her mistress 'is preparing a monstrosity greater even than' her early mania, magic and theomachy (maius his, maius

61. The seminal work on the comparatiuus Senecanus is of course Seidensticker (1985), and see also Schiesaro (2003), esp. 34f., 130f.

62. The notion is recapitulated by Oedipus himself at Phoen. 264-73. On this passage and incest as a greater crime than parricide throughout the play, see Ginsberg in this volume.

63. Again, see also Ginsberg in this volume.

64. Esp. Boyle (1997), 112-37; Boyle (2006), 208-18; Mader (2002a); Schiesaro (2003); Littlewood (2004); Erasmo (2005), 122-39; Frangoulidis (2009); Winter (2014). See also Mowbray (2012) on internal audiences. 


\section{ROBERT COWAN}

parat / Medea monstrum. 674f.) These passages, and others from across the Senecan corpus, look back to the final line of (one) Ovidian Medea's letter to Jason: nescioquid certe mens mea maius agit! ('My mind is certainly agitating/ acting something greater!' Ov. Her. 12.212). This line, as Barchiesi and Hinds noted independently and simultaneously in 1993, has a generic dimension, adumbrating Medea's role in the 'greater' genre of tragedy, and more specifically in Ovid's own Medea. ${ }^{65}$ Already in Heroides 12, the maius-motif has a double sense, not simply that tragedy is 'greater' than the lesser genre of elegy, but that it is excessive, transgressive, not only 'more' but 'too much', a similar doubleness to that in Juv. 6.635 when tragic satire crosses the bounds, not just of satire's lex generis, but of everything. When the motif is transplanted to tragedy, the generic contrast fades, since Medea and the others are no longer aiming higher than elegy or satire, or rather it collapses in on itself, since they aim to be more tragic than tragedy, to attain an excess of its own excessive nature.

These motifs of moreness and metatheatre are particularly concentrated in Atreus' famous speech to (or at least in the presence of) the satelles ('attendant'), plotting revenge upon Thyestes:

nescioquid animo maius et solito amplius supraque fines moris humani tumet instatque pigris manibus - haud quid sit scio, sed grande quiddam est. ita sit. hoc, anime, occupa (dignum est Thyeste facinus et dignum Atreo, quod uterque faciat): uidit infandas domus Odrysia mensas-fateor, immane est scelus, sed occupatum; maius hoc aliquid dolor inueniat.

(Sen. Thy. 267-75)

Something in my soul greater and bigger than usual, and beyond the limits of human custom swells and urges on my indolent hands-I do not know what it is, but it is something grand. So be it. Of this, my soul, take possession (worthy of Thyestes is the crime and worthy of Atreus, for either to commit): the Thracian house saw an unspeakable banquet-I admit it, the crime is huge, but taken; something greater than this let my anguish find.

65. Barchiesi (1993), 343-45; Hinds (1993), 41-43; cf. Williams (2012). Hinds has more recently gone on to trace the motif through Senecan tragedy and to argue that characters as diverse as Phaedra, Oedipus and Atreus 'in intertextual terms ... are in a sense all becoming Medeas' (Hinds [2011], 26, original emphasis). 


\section{BLOATED BUSKINS}

While the excessive size of everything, physical and emotional, in the tragedies serves to trope the grandiosity of the genre (and is troped by it in turn), the parallelism is particularly clear when, as here, they are connected to a plot which is a mise-en-abîme for the tragedy as a whole. This passage is amongst the most-discussed of all in the corpus, and it is well-known how the corporeal image of Atreus' emotional swelling, informed by the physiognomic ideas Seneca famously expresses in De ira, morphs into the excessive enormity of his plot. Likewise, his determination to transgress boundaries and surpass predecessors is part simultaneously of his psychopathology and of his emulative poetic ambition. The emphasis on aemulatio, the way in which the 'Senecan protagonist drives revenge ... through a metatheatrical prism, employing a rhetoric of amplification to outdo past crimes and past tragedies', is unquestionably an important dimension of the metatheatrical and metapoetic roles of Atreus, Medea, Juno and others, but it is not the only one. ${ }^{66}$

Seneca's embedded tragedians are bent not only on going beyond tragic predecessors, but on going beyond everything, because that is the nature of tragedy. Schiesaro has emphasized the way in which this same rhetoric of amplification, even pushed to the point of an insanity which shades into vatic inspiration, can render Atreus a figure of the sublime straight out of Longinus. ${ }^{67}$ This is a powerful reading and one which I do not wish to refute, but it stands in exquisite tension with the danger, ever-present in all discourses of the sublime and of poetic elevation more broadly, that sublimity can tip into excess, grandeur into grandiosity, Longinus' idea of the sublime into the satiric idea of tragedy. It is just such a tipping which Seneca inscribes in Atreus' succumbing to excess, just as he does with Medea's moreness and Juno's method-acting madness. It would be possible to read such figures as failed tragedians, who reach for the sublime but lapse into bombast. ${ }^{68}$ Yet the ubiquity we have seen of immensity, excess, 'moreness' in Senecan tragedy encourages the audience to see these characters as not anomalous but synecdochic, their metatheatrical projects as producing a mise-en-abîme of the tragedies they are in. These tragedies, frame and inset, are not bad tragedies as opposed to good, but bad because that is the nature of tragedy, to have an overblown aesthetic which parallels its overblown passions and overblown bodies. Or rather that is the nature of tragedy according to satire, an idea which Seneca is exploiting for his own ends.

Within the (so to speak) larger category of immensity and excess, several more specific motifs and terms are shared by Seneca's practice and satire's idea of tragedy. The notion of tragedy as monstrum in form and content is an obvious point of correspondence between the satiric idea (particularly prominent in Martial but detectable throughout the tradition all the way back to Lucilius)

66. Buckley (2013), 211.

67. Schiesaro (2003), 127-32. Cf. Littlewood in this volume on the sublime in $H F$.

68. Cf. Chaudhuri (2014), 136-44, on Hercules in $H F$ as a failed sublime author figure, set in antithesis to Atreus' mastery. 


\section{ROBERT COWAN}

and Seneca's self-conscious practice. As ever, there is interplay between the aesthetic metaphors of form and the concrete physicality and emotional metaphors of content: Senecan tragedy contains monsters who behave monstrously and that both tropes and contributes to making the genre itself a monster. ${ }^{69}$ Staley has recently offered a persuasive analysis of this motif so that I can and should be brief here. ${ }^{70}$ I am not entirely convinced by Staley's emphasis on monstra as things which monstrant, 'reveal', and still feel that the audience's inability to process and comprehend the category-blurring of the Senecan grotesque is an integral part of its monstrosity, but this issue does not directly affect the present argument. Staley also skilfully demonstrates Seneca's engagement with critical theories of tragedy, in this aspect as in others, to show that 'Seneca's application of Aristotelian principles produces tragedy that is, paradoxically, un-Aristotelian precisely because it is monstrous tragedy'. ${ }^{71}$ This notion that Seneca does not merely take a slightly or even substantially divergent view of tragedy, but rather takes what is the essence of bad tragedy in Aristotelian terms as the essence of all tragedy means, as we have seen, that he is making exactly the same move as satire.

The other subset of tragic excess which is particularly common in both satire and Seneca is an emphasis on 'swollenness', tumor, its cognate adjective tumidus and verb tumesco, along with forms of turgeo. Persius vividly writes of 'swollen cheeks' (tumidas...buccas, 5.13) and not wishing that 'with trifles dressed in mourning my page should swell' (pullatis ut mihi nugis / pagina turgescat, 5.19f.), while Martial associates tragedy with the 'swollen schoolmaster' (tumidus...magister, 8.3.15) and insists that 'nor does my Muse swell with frenzied tragic robe' (Musa nec insano syrmate nostra tumet, 4.49.8). In addition to its frequency, it has the virtue (or vice) of being unambiguously pejorative in its three overlapping functions as an aesthetic, psychological and physical term. It should be acknowledged again that, as with much of the language of elevation, in satire and elsewhere, 'swollenness' is also attributed to epic and other poetry which does not fit the ideal of Callimachean $\lambda \varepsilon \pi \tau$ ó $\tau \eta \varsigma$ ('fineness'), perhaps most famously in Catullus' reference to 'swollen Antimachus' (tumido...Antimacho, 95.10) and Horace's to the 'swollen Alpine' (turgidus Alpinus, S. 1.10.36), who may or may not have been Furius Bibaculus qua epicist of Caesar's campaigns. As argued in section 2, the metaphor's association with elevated poetry in general is, in most cases, sufficient for it to be associated with tragedy as a subset of such poetry when it is activated in a tragic context. Yet we shall conclude with a marginal case, where it is less clear whether Seneca is exploiting the satiric idea of tragedy or of epic.

69. On the metapoetics of monstrosity, focusing on Augustan epic but applicable to other elevated genres in other periods, see now Lowe (2015).

70. Staley (2010), 96-120.

71. Staley (2010), 113. 


\section{BLOATED BUSKINS}

Swollenness is ubiquitous in Senecan tragedy. While its ready application to each of the three realms of the physical, emotional and aesthetic already facilitates the sense of interconnection between them, the notion that physical distention, emotional anger or arrogance, and aesthetic bombast are all facets of an overarching quality of swollenness is given tangible support in Seneca's prose writings. Critics rightly stress the importance of his physiognomic connection of the swollen face with the swelling of anger at De ira 1.1.4. ${ }^{72}$ Within the plays, emotional tumor is usually associated with anger, arrogance, or a combination of the two, often marked as the quality of the tyrant. ${ }^{73}$ The chorus in Thyestes blurs the relationship of the emotional and the physical in urging kings to 'lay aside their overblown and swollen uultus' (ponite inflatos tumidosque uultus, 609), where uultus signifies both the 'expressions' reflecting their arrogance and the 'faces' with the physical distension physiognomically caused by it. Indeed the aesthetic dimension is also evoked stylistically since 'the combination is conspicuously orotund, matching the state described'. ${ }^{74}$ Tragic bombast describes the swollen face of the tyrant's arrogance, each one a tumor. More impressionistically, the Nurse's description of Medea's magical rites shifts from the 'swollen body' (tumidum...corpus, 689) of a snake she is using into the report of Medea's speech, swelling with ambition and the impulse to 'moreness', to 'something higher' (aliquid...altius, 693), to the tragic grandeur and grandiosity to which she as a dramaturge-figure aspires. In this context, it is worth noting that Atreus' metatheatrical project (Thy. 267-75, quoted above) is prefaced by the image of either his mind or the 'something greater' itself swelling (tumet, 268, the subject depending on whether one reads the MSS animus or Leo's animo).

This more impressionistic connection of the physical, emotional and aesthetic is played out with particular subtlety in $H F$ and Oedipus. In Oedipus, the swelling of Oedipus' foot when pinned to the ground as part of his exposure as a baby links to the swelling of his tyrannical anger, both connected through bilingual etymology to his name. ${ }^{75}$ The anger, the inflammation, and the infection of mind and body, madness and plague, which spread from these are made emblematic of the man and the tragedy that is Swellfoot. Physical tumor is a recurrent feature of the monsters and forces of nature which the civilizing Hercules must overcome, the serpents Juno sent against him as a child (221), the poisonous plants which will be banished by the Golden Age he plans to usher in (936), the seas which are one of the three realms he has conquered (955), and even the absence of swelling waves is noted among the features which make the

72. E.g. Boyle (2014), 178 ad Med. $177 f$.

73. Anger: Ag. 126f., Pho. 352-54, Thy. 519, 737, Tro. 586; arrogance: Ag. 247f., 958, Med. 178, Pha. 137, Pho. 584f., Thy. 609.

74. Tarrant (1985), 178 ad loc.

75. Exposure: Oed. 857-59; etymology: 812f. Boyle (2011), 305f. ad 857-9: 'Phorbas is about to experience the tumor of Oedipus in a different sense: the anger of the tyrant. ... the use of lues to connote the "infection" attacking the baby's wounds is not accidental. Seneca suggests verbally the origins of the Theban plague in the wounds of Oedipus.' 


\section{ROBERT COWAN}

underworld an uncanny and unHerculean place (550f.). Emotional and political tumor is also a feature of the tyrant Lycus, and one which Megara specifically frames as being one he can enjoy for only a limited time, since an 'avenging god' (ultor ... deus), be it Nemesis or Hercules himself, is at his back (384f.). Yet throughout the play, Hercules shows the fatal tendency to become assimilated to the monsters he defeats, ending with his becoming a monster himself. ${ }^{76} \mathrm{Her}-$ cules' greatness and justified pride in his prowess easily can and duly does shade into swollenness and arrogance. Even allowing for her hostility, the audience can find ample corroboration for Juno's claim that Hercules is aiming to storm the heavens, 'swollen with the strength that he has put to the test' (robore experto tumet, 68). The grandiosity and the arrogance of both Hercules and his foes, the hyperbolic ambition of his theomachic project, all are the very stuff of tumor tragicus.

We now approach the limits of the association of tumor with tragedy, and in particular the boundary beyond which its connection with epic is stronger. tumidus and its cognates are most frequently used in the tragedies to describe the sea, its waves, or the winds which themselves swell and in turn cause the sea to swell. Often the connection with the tumor of ira or furor is explicit, or all but so, as the sea is a simile for the passions. ${ }^{77}$ Thus the chorus note that the sleeping Hercules' madness has not yet entirely passed and he is still showing residual symptoms:

nec adhuc omnes expulit aestus,

ut ingenti uexata noto

seruat longos unda tumultus

et iam uento cessante tumet.

(Sen. $H F$ 1088-91)

Nor yet has he driven out all the billows, just as, harassed by the huge south wind, waves maintain a long-lasting turmoil and, though the wind is already easing, still swell.

Here the interconnectedness of the physical and emotional tumor is further underlined by the figura etymologica linking tumultus with tumeo, and by the 'trespass' of aestus from the vehicle into the tenor, a metaphor described by a simile. ${ }^{78}$ The

76. $H F$ 1279-81; cf. 939. Chaudhuri (2014), 125: 'Hercules is assimilated to the monsters he has conquered'; Bishop (1966), 220: 'Hercules and Lycus ... are men of the same basic quality.'

77. In addition to the passages quoted below, Thy. 957-60 also explicitly links the swollenness of the sea and the passions. Swollen seas with no such explicit link: Ag. 408, 450, 469, HF 550f., 955, Oed. 450, Thy. 291, 361f., Tro. 880; cf. Phoen. 609 on the River Xanthus, swollen with the snows of Mt. Ida.

78. On 'trespass' in similes: Lyne (1989), 73f. As Fitch (1987), 401 ad loc., notes, this also applies to the resumptive fluctus ('waves') in line 1092. 


\section{BLOATED BUSKINS}

blurring of vehicle and tenor is even more extensive in the first stanza of the Medea's third choral ode, the first of four whose sweeping Pindaric torrent bursts the bounds of its Sapphic quatrains. It is not only more extensive but even more thematically significant, as Medea without (wedding) torches burns with more force than fire (nulla uis flammae / ... tanta... / quanta cum coniunx uiduata taedis / ardet et odit, "no force of fire is as great as when a wife deprived of her marriage burns and hates', 579-82), or than 'swollen and swelling winds' of a sea-storm (tumidiue uenti, 579). Medea is a force of nature and the interchangeability of the terms both reinforces the parallels between psychic and cosmic disorder, and admits that any attempt to define either is doomed to failure. ${ }^{79}$ Theseus collapses the distinction between the literal and metaphorical, the physical and the emotional, exploiting his father Neptune's status as simultaneously sea and anthropomorphic god, demanding that he become 'swollen', implicitly with both seawater and anger, and 'summon waves from Ocean itself' (fluctusque ab ipso tumidus Oceano uoca, Pha. 958). We thus have a particularly marked interrelation of the physical and emotional connotations of 'swollenness', which is already an image with particularly strong poetological overtones.

Moreover, the sea (including sea-voyages) is a common metaphor for elevated poetry. However, unlike the grandeur and grandiosity which we have seen moreor-less equally applied to epic and tragedy taken as a pair, sea imagery is very strongly associated with epic. ${ }^{80}$ Indeed, tumidum mare ('swollen sea'), precisely the same iunctura, is used in an explicitly metapoetic context by Propertius when he writes a recusatio (at least ostensibly) in response to Maecenas' request for an epic. ${ }^{81}$ It is probably no coincidence that this same iunctura occurs twice within fifty lines of Eurybates' messenger speech about the very epic storm which scattered the Greek fleet returning from Troy. ${ }^{82} \mathrm{With}$ the swollen sea, we are pushing the limits of the satiric idea of tragedy. Sometimes, as in Agamemnon, it can be productive to read the image as specifically epic, in contrast to its tragic context. On other occasions, the temptation is to allow the loose association with tragedy,

79. 'A series of analogies between the force of Medea's anger and hate and that of violent natural phenomena which destroy the works of man', Boyle (2014), 275 ad 579-94. 'The passions, the tides and the orbits are phenomena of the same kind, are causally interrelated, and can be discussed in interchangeable terms.' Herington (1966), 433 on Senecan tragedy in general, aptly applied by Henderson (1983), 96 to this stanza. Henderson (1983), 95: 'Medean uis ... beggars description: woman, "locus of disorder", exceeds language, normal categories are inadequate.'

80. On the image of the sea as epic: Lieberg (1969); Morgan (1999), 32-39 (specifically Homer); Harrison (2007b). On swollen seas and epic: Ov. Met. 14.4, with Myers (2009), 53f., and Tr. 1.2.23f., with Ingleheart (2006), 87f.

81. non ego uelifera tumidum mare findo carina (' $I$ do not cleave the swollen sea in a sail-bearing ship', Prop. 3.9.35). Ross (1975), 123 n.1, notes that 'the epic formation velifera is a nice touch'; Heyworth and Morwood (2011), 191 ad loc.: 'the return to sailing imagery...is compounded by the epic compound epithet and the anti-Callimachean tumidus.'

82. Ag. 408, 450. Cf. agitata uentis unda uenturis tumet ('the wave swelled, stirred by winds to come', 469). On epic features in this speech, see Baertschi (2010) and Gunderson in this volume. 


\section{ROBERT COWAN}

as the other elevated genre, to remain, but this extreme case does pose important questions about just how flexible the image is.

As we reach the limits of Seneca's engagement with the satiric idea of tragedy, it is time to address the one aspect of that idea-only one, though arguably the overarching one-which he does not accept and appropriate, that of tragedy's irrelevance to contemporary 'real life'. Since the refutation of this charge involves competing with and drawing parallels with satire itself (or its own self-construction), we must examine Seneca's use of satiric features within his tragedies, both as markedly alien generic intrusions and as qualities shared by these two ugly sisters.

\section{Bigots in Buskins? Seneca and the Tragic Idea of Satire}

The presence of other generic elements within Senecan tragedy has been uncontrovertibly demonstrated. Lyric, and specifically Horatian lyric, is an interesting but special case, since its position within the choral odes of Senecan tragedy constitutes a generic intrusion only to the same extent as in the parallel relationship of archaic and classical lyric genres within Attic tragedy, a relationship further complicated by the latter's (probable) origins in dithyramb and other choral lyric. ${ }^{83}$ The relationship with epic has always been a privileged one, especially in the narrative messenger speeches (an affinity already present in Attic tragedy), but also in more specifically Senecan features such as developed 'epic' similes and intertextuality with the Aeneid. ${ }^{84}$ Generic engagement with the erotic discourse of elegy (often overlapping with more author-specific intertextuality with Ovid) has been an area to which increasing attention has been paid in the last decade. ${ }^{85}$ Even the presences of pastoral and iambos have been detected, the latter in a particularly interesting exploration of how Seneca's Medea receives Horace's own reception, in the Canidia of the Epodes, of earlier tragic Medeas. ${ }^{86}$

On one level, an admixture of diverse generic elements is part of Seneca's conception of tragedy, though even this does not preclude an element of self-consciousness. ${ }^{87}$ Particularly significant (for the current argument at least) within this body are those studies which move beyond models of contaminatio or a more-or-less Krollian Kreuzung der Gattungen to look at the self-conscious employment of generic discourses. Such self-consciousness can be shown by

83. Horatian lyric in Seneca: Spika (1890); Degl'Innocenti Pierini (1992); Stevens (1999); Lenzi (2006); Trinacty (2014), 144-64. Lyric genres in Attic tragedy: Swift (2010).

84. Tietze (1989); Aygon (2010); Pypłacz (2010), 29-59; Baertschi (2010); Baertschi (2015); Schiesaro (2014).

85. Elegy: Janka (2004); Morelli (2004); Littlewood (2004), 259-301; Rosati (2006); Trinacty (2007); Trinacty (2014), 65-126; Ginsberg (2015). Ovid: Hinds (2011); Walsh (2012).

86. Pastoral: Schiesaro (2006). Iambos: Degl'Innocenti Pierini (2013).

87. Tarrant (1995), 225: 'Seneca applies to tragedy the blending of genres so widely practiced by the major Augustan poets.' 


\section{BLOATED BUSKINS}

characters, as in Trinacty's reading of Pha. 609-12 where he argues that 'Phaedra attempts to reformulate her relationship with Hippolytus in accordance with elegiac standards', or by the tragedies themselves, as when Ginsberg construes the presence of elegiac topoi in Phoenissae as part of a totalizing project which 'highlights the prowess of Seneca whose poetics turn all genres into the materies of tragedy.' 88 Yet the presence of satire or satiric elements has been almost entirely neglected. The single study, to my knowledge, which has looked at satire in the tragedies is an insightful but restricted discussion by Michael Coffey, who detects satiric themes in Thyestes' praise of the simple life at Thy. 446-70, and pairs it with an epic example of 'generic impropriety' in Lucan's depiction of Cleopatra's court in book 10 of the Bellum Ciuile. ${ }^{89}$

The importance of Coffey's article should not be understated, both as a rare, perhaps unique, acknowledgment of Seneca's employment of the satiric mode in his tragedies, and for the valid point it makes about Thyestes' speech rejecting wealth and status at Thy. 446-70. ${ }^{90}$ Yet its aims and, as a result, its scope are strictly circumscribed, both in its limiting of the idea of satire to contemporary moralizing discourse, and even in its singling out of this speech as the sole example of such moralizing in the tragedies. Even the discussion of Thyestes' speech itself could be expanded to acknowledge further satiric features. Coffey's summing up of the speech as 'a passage of high poetry which, while retaining the dignity of language appropriate to tragedy, consists of themes of satirical moralizing' is in itself a suggestive formulation, and could be read as a witty inversion of satire's own practice of using incongruously low language to describe the lofty themes of tragedy (as well as epic): ${ }^{91}$

nulla culminibus meis

imposita nutat silua, nec fumant manu

succensa multa stagna, nec somno dies

Bacchoque nox iungenda peruigili datur.

(Sen. Thy. 464-67)

\section{No forest set on my roofs}

nods, nor do pools steam, by many a hand

heated from below, nor to sleep is my day given, and to wakeful Bacchus my night, ready to be joined to it.

88. Trinacty (2014), 84; Ginsberg (2015), 228.

89. Coffey (1996).

90. Moralizing is so fundamental to the theory and so pervasive in the practice of Roman satire that it is almost redundant to provide examples, though instances of specific techniques and targets of satiric moralizing are provided in the paragraphs below. Some notable instances (among many) of satire's self-construction as a moralizing genre include Hor. S. 1.4.103-31, 2.1.62-65, Pers. 5.15f., Juv. 1.81-90 (indeed Juv. 1 passim). Praise of the simple life (often ironized or undercut) is especially prominent in Hor. S. 2.2, Pers. 6, Juv. 3 and 14.

91. Coffey (1996), 86. 


\section{ROBERT COWAN}

Satire produces dissonance by describing Thyestes' and Tereus' tragic banquets in markedly untragic diction as a pot or a brunch. ${ }^{92}$ Tragedy here reciprocates by turning a roof-top garden into a silua and baths into stagna, and metonymizing wine into Bacchus. ${ }^{93}$ This is more than generic tit-for-tat, and can be read as a response to the implication that the remoteness of tragic diction from everyday language is both symptomatic and mimetic of its inability to engage with the important issues of 'real life'. If, as Hutchinson interprets Persius 5.17f., 'starkly concrete language brings to a height the grotesque outlandishness of the tragic world; low and humdrum terms present, with relaxed irony, the Roman reality that matters', then Seneca here asserts that, on the contrary, tragedy can cope with contemporary moralizing themes, and indeed can do so without in any way compromising its generic status by lowering its stylistic register. ${ }^{94}$

Such an interpretation of tragedy's polemical stance vis-à-vis satire works on one level, but it largely presupposes that the audience takes the moralizing discourse 'straight' and does not consider the dramatic context or the characterization of the speaker. Coffey too ignores (or perhaps tacitly dissents from) the communis opinio about Thyestes' praise of the simple life. Some scholars do indeed take the speech as a straightforward reflection of Thyestes' genuine, deep-seated moral outlook and thus read him as a Stoic proficiens, if not sapiens. ${ }^{95}$ However, the majority, on the basis both of internal consistencies within the speech itself and especially Thyestes' subsequent rapid and easy capitulation to persuasion first by his son and then by his brother, take a more complex view. Whether Thyestes' moral insight is genuine but shallow-rooted and easily overpowered by his overwhelming Tantalid appetite, as Boyle argues, or his pretensions are more comprehensively self-deluding, generating,

92. olla Thyestae, Pers. 5.8; Bramble (1974), 56: 'He then proceeds to mock the two most horrific tragic banquets, which he dubs with the vulgar deflatory olla.' Compare prandia saeui / Tereos, Mart. 4.49.3f., diri prandia...Thyestae, 10.35.6. Citroni (1968) 279, argues that Martial is directly alluding to Persius 5: 'Le «mensae » di Micene sono $\mathrm{i}$ « prandia saeui Tereos » di Marziale IV 49, 3 sg. Abbandonare i banchetti di Micene significa accostarsi ai banchetti di ogni giorno: «plebeia prandia»' (The mensae of Mycenae are the prandia saeui Tereos of Martial 4.49.3f. To abandon the banquets of Mycenae means to turn to the banquets of everyday life: plebeia prandia). Of course, this directly transgresses the rule laid down at Hor. AP 90f. On incongruous diction in Juvenal, see esp. Schmitz (2000), 97-107. Cf. Morgan (2005), 185, on epic and unepic language at Juv. 10.61-64: 'The violence done to elevated modes of speech precisely reflects the violence being done to a former symbol of authority. Sejanus was great, and the epic language of toto orbe secunda expresses this at a stylistic as well as semantic level. What he, or rather his statue, becomes, on the other hand, is both base-kitchenware and toiletries - and basely expressed in a plain, unembellished list of words which themselves have no possible place in respectable literature.'

93. stagnum only occurs in satire at Juv. 12.81, hyperbolically evoking the calmness of Trajan's rebuilt Portus Augusti at Ostia (see Courtney [1980], ad loc.); silua occurs five times each in Horace's Satires and Juvenal, always of actual forests except at Juv. 9.13, where it is used metaphorically of hair; Bacchus does not occur in extant satire, either as metonymy for wine or in any other sense.

94. Hutchinson (1993), 28.

95. Gigon (1938), 180-83; Marti (1945), 239-41; Herington (1966), 458-60; Hine (1981), 272f.; Monteleone (1991), 253-55. 


\section{BLOATED BUSKINS}

as Schiesaro puts it, 'the suspicion that he is appropriating the rhetorical stance of a Stoic sage without real conviction', there is a broad consensus that, to quote Schiesaro again, 'we cannot accept Thyestes' impassioned lines at face value' ${ }^{96}$

Once the satiric moralizing embedded within this tragedy is seen to be basically hollow, several other layers of complexity can be perceived. On what is still a relatively simple level, it can be seen as another act of intergeneric polemic, tragedy disparaging satire's claims to offer moral teaching. However, since this reading insists on giving full weight to the characterization of Thyestes and the distinction between his words and any overarching 'message', it should be remembered that satire also frequently employs embedded characters whose moralizing assertions are implicitly or explicitly problematized. Examples include Horace's Ofellus, Damasippus and Davus, Persius' Socrates, or Juvenal's Laronia, Umbricius and Naevolus. On this level, Senecan tragedy is acknowledging and imitating satire's own practice. From here, one final layer of complexity may be added by noting that such embedded moralizers in satire are often read as satirist-figures, whose shortcomings may either draw attention to similar defects in the moral stance of the primary satiric persona, or more polemically set up a negative exemplum of the sort of flawed satirist to contrast with the ego-figure. ${ }^{97}$ In particular, scholars have repeatedly observed the way in which Thyestes lavishes disproportionate space and luxuriance of detail on the luxuries he claims to reject. ${ }^{98}$ This closely resembles the prurient fascination which the satirist or embedded satirist-figure has with the vice he purports to condemn. ${ }^{99} \mathrm{On}$ this level, tragedy is still polemically disparaging satiric moralizing, or at least exploring its contradictions and limitations, but it is doing so in parallel with and perhaps imitation of satire's own self-reflexive practice of examining its own nature through the presentation of embedded satirist-figures.

Another direction in which Coffey's analysis might be extended is to note that Thy. 446-70 is far from unique within the corpus of Senecan tragedy in its inclusion of satiric moralizing. Some examples set up a similar relationship to satire,

96. Schiesaro (2003), 149 (cf. 57). Cf. Boyle (1983b), 216: 'Dissidence between personal appetite, on the one hand and moral knowledge and moral responsibility on the other seems central to Thyestes' dramatisation'; cf. id. (1997), 23f. Similar is Littlewood (1997), 69, on the dehumanizing hunger which produces 'such a violent dislocation in the characterisation of Thyestes'. Even more cynical about Thyestes are Tarrant (1985), 43-45, 148-59 and Davis (2003), 66f.

97. In general, see Plaza (2006), 167-256. Damasippus and Horace: Harrison (2013), 158-60. Umbricius as Juvenal: e.g. Keane (2002), 227f. ; Umbricius as not-Juvenal, see Staley (2000), 86: 'Umbricius is [not] an alter ego for Juvenal himself...but rather...an embodiment of Juvenal's constructed image of the "satirist".' Naevolus: Braund (1988), 130-77, esp. 170; Rosen (2007), 22335. Moodie (2012) even makes a (convincing) case for the thug of Juv. 3.278-301 as a satirist-figure.

98. Boyle (1983b), 216: 'though he praises the life of hardship and obscurity, Thyestes' defence of that life is in decidedly negative terms ... and results in his dwelling on those aspects of the life of power in virtue of which it is normally desired.' Davis (1989), 427: 'Thyestes ... juxtaposes a fairly colourless account of the life of virtue ... with a vivid account of the life of vice in very Roman terms'. Cf. Tarrant (1985), 155f., esp. ad 446-70 ('gusto') and 455-69.

99. E.g Littlewood (2002), 57, on Persius' Socrates; Braund (1988), 130-77; and Rosen (2007), 223-35 on Juvenal's Naevolus. 


\section{ROBERT COWAN}

depicting flawed satirists whose compromised depiction is partly polemic against, partly imitation of that self-destructive genre. When Phaedra's Nurse attributes her mistress's lust to the effects of success, wealth and luxury, she unquestionably 'attacks, in terms which are those of traditional satire, the hypocrisy of the upper classes and their spoilt child's whims'. ${ }^{100}$ There are even some striking echoes of thought and language between her sermon and those in satire, and even if we imagine that, for example, Juvenal is directly imitating Seneca here, it is surely no coincidence that the tragic satirist chooses a passage of particularly satiric tragedy. ${ }^{101}$ Yet the integrity of her moralizing stance is thrown into question by her volte-face in the face of Phaedra's threatened suicide (267-73) and by the equal intensity and virtuosity of her opportunistic arguments in favour of sexual licence in her agon with Hippolytus (435-82). Hippolytus' own reply develops a satiric strain of moralizing, but one whose validity is undermined by the characterization of its speaker and his motives as rabidly misogynistic, a diatribist with a hidden agenda straight out of book 2 of Horace's Satires or book 1 of Juvenal's. ${ }^{102}$

Yet not all satiric intrusions into Senecan tragedy are ironized. On other occasions, the satiric mode is appropriated rather than framed, assimilated rather than objectified, as tragedy asserts its affinity with rather than superiority to satire. Such moments are particularly common in the choral odes. The Senecan chorus is an elusive entity, object of much discussion and much abuse. ${ }^{103}$ It would be extremely reductive to see it as providing an unmediated 'voice of the author', but its motivations, perspectives and prejudices are rarely as articulated as those of individual characters and, like the Attic tragic chorus, its utterances, in particular its cosmic and ethical pronouncements, often take on a degree of universality. ${ }^{104}$

A powerful example of this is the first ode of the $H F$, often called the 'Dawn Song', whose immense programmatic and thematic significance has been repeatedly demonstrated. ${ }^{105}$ Following a reflection, closely modelled on the parodos of Euripides' Phaethon, upon the desirability of the quiet, rustic life, the chorus ushers us into a satiric cityscape as hectic as Lucilius fr. 1228-34 Marx,

100. Sen. Pha. 204-14; Dupont (1995), 239: 'elle s'attaque, dans des termes qui sont ceux de la satire traditionnelle, à l'hypocrisie des classes supérieures et à leurs caprices d'enfants gâtés.'

101. turpi fregerunt saecula luxu / diuitiae molles. quid enim uenus ebria curat? ('Enervating riches enfeebled the generations with foul luxury. For what does drunken lust care?' Juv. 6.299f.), with Pers. 1.67, one of only two occurrences of luxus in extant satire.

102. '[Hippolytus] closes his speech in praise of country life with a fanatical denunciation of women. The lack of logical connection between the preceding panegyric and the condemnation of women underlines the irrationality of his misogyny and suggests that his hatred is innate rather than reasoned.' Davis (1983), 119. Cf. Boyle (1997), 64.

103. On the Senecan chorus, see esp. Davis (1989), (1993); Hill (2000).

104. On choral characterization: Davis (1993), 39-62.

105. On the 'dawn song': Bishop (1966), 218-22; Rose (1985); Mader (1990); Davis (1993), 12636; Littlewood (2004), 107-14. 


\title{
BLOATED BUSKINS
}

Horace Satires 2.6.23-31 or Juvenal 3, peopled with Horatian misers and downtrodden clients straight out of Martial and Juvenal:

\author{
haec, innocuae quibus est uitae \\ tranquilla quies \\ et laeta suo paruoque domus. \\ spes immanes urbibus errant \\ trepidique metus. \\ ille superbos aditus regum \\ durasque fores expers somni \\ colit; hic nullo fine beatas \\ componit opes, \\ gazis inhians \\ et congesto pauper in auro; \\ illum populi fauor attonitum \\ fluctuque magis mobile uulgus \\ aura tumidum tollit inani; \\ hic clamosi rabiosa fori \\ iurgia uendens \\ improbus iras et uerba locat.
}

(Sen. $H F$ 159-73)

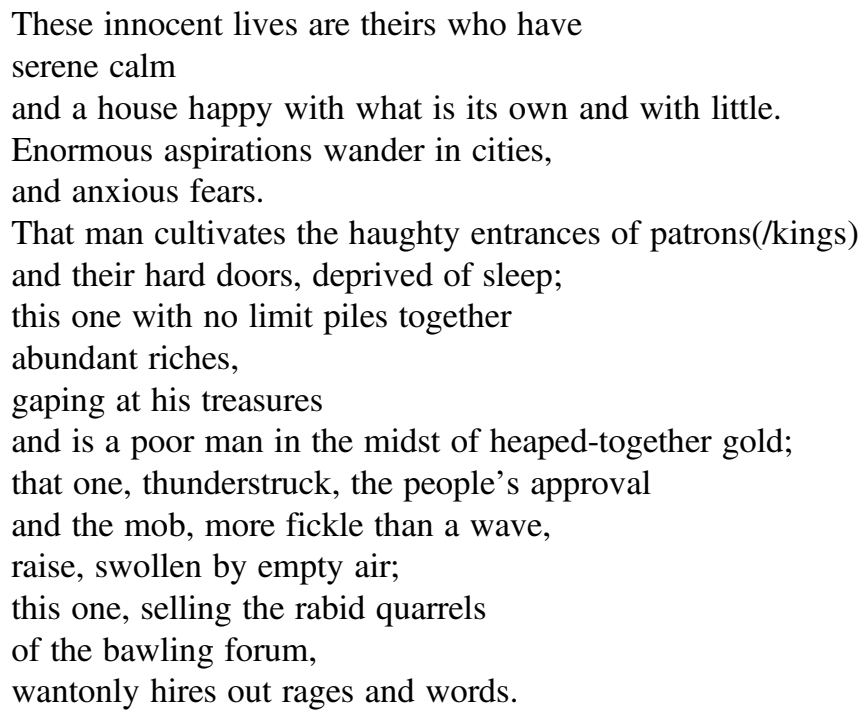

As with all the instances of 'satiric' moralizing, we must acknowledge that elements of the discourse are shared among various genres, such as declamation, didactic and lyric, all of which have a prominent place within the complex fabric of Senecan tragedy. Yet, while such moralizing was one feature among 


\section{ROBERT COWAN}

many in these and other genres, it was the defining essence of satire. Indeed the case can be and has been made for the presence of a satiric voice in various parts of the De Rerum Natura and passages such as the end of Georgics $2 .{ }^{106}$ The latter is particularly pertinent here, since numerous verbal echoes of it have been detected in the 'Dawn Song', and Martyn's identification of satiric elements in the Virgilian passage is persuasive. ${ }^{107}$

We need not go as far as seeing all such passages as quintessentially satiric in the absence of further markers, but the aggressive anachronism of this passage from the Dawn Song is just such a marker. Of course, anachronism also has an important place in Attic tragedy but rarely if ever as marked as here. ${ }^{108}$ Yet the very starkness of the way in which the satiric anachronisms jar against their tragic surroundings stands in exquisite tension with their total integration with the rest of the tragedy of the overliving Hercules. ${ }^{109}$ As Fitch puts it:

the anachronisms work both ways: if they assist a Roman audience in perceiving what is objectionable in Hercules' way of life, they also hint that Herculean ambition and disregard of the evanescent quality of life are ills to be found in contemporary Rome. ${ }^{110}$

If Seneca had merely taken a time-out from his tragic project to show that he could be an effective satirist as well, the very act of demarcating satiric moralizing from tragic platitudinizing would have corroborated the satiric idea of tragedy as fundamentally irrelevant. You can graft vital satire onto the dead wood of tragedy, but it won't take and you'll always be able to see the join. Instead, Seneca uses tragic and satiric modes in tandem to explore themes which are relevant to both genres' constituencies. Satire is not patronizingly doing tragedy a favour by turning its excoriating scrutiny upon the tragic Hercules, or rather it is only doing so in equal proportion to the surrounding tragedy's illumination of the realities of contemporary Rome. Indeed, the division of the ode into sections of which one intertextually evokes Euripides' (and through him Ovid's) tragic Phaethon and the other generically evokes satire still more clearly

106. Satire in Virgil's Georgics: Martyn (1972); Nelis (2004), 75f.; in Lucretius: Murley (1939); Waltz (1948); Dudley (1965); Gellar-Goad (2012); Cowan (2013).

107. Billerbeck (1999), 256f.: 'Hier...erinnert die Beschreibung der geschäftigen Städter...vor allem an die Schlusspartie des zweiten Georgicabuches' (The description here of the bustling city recalls above all the closing section of Georgics book 2). Fitch (1987), 160f., argues for a broader range of influences. Littlewood in this volume offers a persuasive new interpretation of Georgic and Lucretian elements in the ode and the play as a whole.

108. Easterling (1985).

109. Scholars still divide on the character and culpability of Hercules, but for studies stressing his excess and tendency to monstrosity: Henry and Walker (1965); Bishop (1966); Shelton (1978); Fitch (1979); Fitch (1987); Rose (1985); Papadopoulou (2004); Chaudhuri (2014), 116-55. On 'overliving': Wilson (2004), 98-112, esp. 100f. on the dawn ode. Hercules' defenders include Motto and Clark (1981); Lawall (1983); and Mader (1990).

110. Fitch (1987), 162. 


\section{BLOATED BUSKINS}

emphasizes their parallel, synergistic roles. ${ }^{111}$ Seneca here is stressing, not the differences, but the affinities between the genres, the third and final aspect of their relationship which we shall examine.

\section{Bloated Buskins: Satiric Tragedy and Tragic Satire}

As I asserted at the beginning of this article, for all that epic and tragedy are frequently paired as the lofty genres at the opposite end of the generic hierarchy from satire, their respective relationships with satire are markedly different. Indeed, it would not be stretching a point too far to argue that satire and tragedy often stand side-by-side as perversions of the norms and ideals embodied especially (but not exclusively) in epic. The poem which was arguably the foundational text (pun intended) for satire's 'evil twin' relationship with epic perverted not only an emblematic epic scene but also its entire ethos along with its ritual and political significance. Morgan aptly describes it as 'Lucilius' restaging in his book 1 of the concilium deorum from book 1 of Ennius' Annals, Lucilius' satirical gathering naturally taking as its discussion point the destruction of Rome where Ennius' concilium had been concerned with its foundation'. ${ }^{112}$ This trend continues throughout the satiric tradition, from Horace's nekyia in S. 2.5 perverting not only the Odyssey but its (basically) wholesome preoccupation with the preservation of the household and its property into a cynical lesson in legacy-hunting, to Juvenal's various epic parodies such as Umbricius' witness to the sack of a very Trojan Rome and Domitian's council about a turbot. ${ }^{113}$ A comparable pattern may be seen already in Attic tragedy, with its perversion of the Odyssean nostos into the domestic and political chaos of Aeschylus' Agamemnon and Sophocles' Trachiniae, the unwitting return of Sophocles' eponymous Oedipus to his native city, or Neoptolemus' failure even to achieve the adumbrated nostos in Euripides' Andromache, except as a corpse. ${ }^{114}$

111. Cf. Littlewood (2004), 114, though he stresses the Iron Age rather than satiric flavour of the second section: 'Ovid marks the differences between the myth of Phaethon and the degeneration into criminality which follows the end of the Golden Age by presenting them in parallel in his narrative. Seneca creates a single, ambivalent hero by characterizing him as a figure from these dissimilar but related myths.'

112. Morgan (2004), 8f. (original emphases). Cf. Morgan (2010), 316: 'Lucilian hexametrical satire, an extended exercise in misusing the metre of heroes which precisely matches the antipathy to the values represented by the epic genre that is of the very essence of the satirical (anti-)genre.' Cf. also Connors (2005), 127-29.

113. Hor. S. 2.5 with Roberts (1984) and Connors (2005), 135f.; Juv. 3 with Staley (2000) and Baines (2003); Juv. 4, with Connors (2005), $142 \mathrm{f}$.

114. Alexopoulou (2009), 41: 'nostos is usually presented as perverted or problematic in Attic tragedy. ... return in the tragic plot is not always achieved for the maintenance of social and personal order, as in the Odyssean nostos, but it reveals the problematic nature of nostos in its numerous possibilities as a return especially associated with revenge...or as a perverted recognition'; cf. 37-82 for her full discussion of tragic nostoi. 


\section{ROBERT COWAN}

Both genres are also marked, almost defined, by their perversion of social, religious and political practices, which are less overtly linked with-though by no means independent of - their literary instantiations. ${ }^{115}$ While dystopian social disintegration in general is a feature of both tragedy and satire, the parallel between the two can perhaps most clearly be seen in the breakdown, or rather the perversion, of the bonds of $\phi i \lambda i \alpha$ and amicitia. ${ }^{116}$ In Attic tragedy, kinkilling, violence towards other friends and allies, and other violations of $\phi i \lambda i \alpha$ are virtually ubiquitous, as well as having Aristotle's seal of approval as suitably terrible and pitiable. ${ }^{117}$ In Seneca, the killing of husbands, wives, fathers, sons, brothers and nephews is central to all eight genuine plays except Troades as well as to the Octavia and Hercules Oetaeus. Satire, especially that of Horace and Juvenal, is preoccupied with the perversion of amicitia, above all the relationship between patron and client. ${ }^{118}$ Religion too is perverted in both genres, particularly its rituals, as befits Graeco-Roman religion's emphasis on orthopraxy, but also its beliefs and prayers. Tragic sacrifices are of humans rather than animals and destroy rather than reinforce social cohesion. Tragic weddings are to death or to those whom it is taboo to wed. ${ }^{119}$ Satire's perversions of ritual are less deadly but no less destructive of the psychic, social and cosmic cohesion which they are supposed to reinforce. Satiric wedding processions lead to the squeezing out of carbon-copies of adulterous gladiators, an evil which apotropaic laurel-wreaths cannot ward off, satiric prayers are either unanswered or, worse, answered. ${ }^{120}$

Satire and tragedy stand as parallel literary perversions of epic as well as sociocultural perversions of all the constructive values for which epic traditionally stands. However, this relationship between ugly sisters itself stands in parallel to the construction of specific tragedies as satiric, comic or parodic distortions of a noble idea of tragedy, one rather different to that we explored in sections

115. Seaford (1989 and 1995) contrasts the perverted sacrifices of tragedy with those in Homeric epic, but the distinction is less between the genres per se than the societies in which they were embedded.

116. The semantic range of $\phi 1 \lambda i \alpha$ is rather broader than that of amicitia, encompassing kinship as well as the social bonds of friendship and political or military alliance.

117. See esp. Seaford (1994), 338-62; Belfiore (2000); Arist. Po. 1453b14-22.

118. LaFleur (1979); Rudd (1986), 126-61; Cloud (1989).

119. On perverted sacrifice in Attic tragedy see esp. Zeitlin (1965); Burkert (1966); Vidal-Naquet (1972); Seaford (1989); Seaford (1994), 369-88; Henrichs (2000); Gibert (2003). On the (Attic) tragic wedding see Seaford (1987); Rehm (1994); Mitchell-Boyask (2006); Swift (2009). Among Seneca's tragedies, perverted sacrifice is particularly prominent in Ag., Tro., HF and Thy.; see esp. Dupont (1995), 189-204; Aricò (2001), 110-13; Schiesaro (2003), 85-98. On the 'polluted sacrifice', extispicy and necromancy in Oed. and their metapoetic connection with tragic contaminatio, see DeBrohun in this volume, as well as Gunderson on the motif of repetition. Ag., Med., Oed., Pha., Phoen., and esp. Tro. foreground perverted weddings: Wilson (1983), 38-40; Boyle (1997), 67-73; Schiesaro (2003), 242-45; and, in this volume, Ginsberg on Phoen. and Sampson on Med.

120. Weddings: Juv. 6.78-81 with Watson and Watson (2014), 101f. ad loc., esp. ad 6.79 on the laurel. Prayer: Pers. 2, with Hooley (1997), 175-201; Freudenburg (2001), 183-88; Juv. 10, with Fishelov (1990). Cf. Boyle (1987), 26 on Sen. Pha.: 'All the prayers uttered in the play... are either unfulfilled or fulfilled in the most ironic and perverse manner' and Secci (2000a and 2000b). 


\section{BLOATED BUSKINS}

one and three above. The notion of comic elements in tragedy, even verging on paracomedy, is of course particularly associated with Euripides, though figures such as Orestes' nurse, Cilissa, in Aeschylus' Choephoroe and the guard in Sophocles' Antigone are also often mentioned. ${ }^{121}$ Of less relevance here is the apparent convergence of comedy and tragedy in the development of late Euripidean 'romance' into Menandrian New Comedy. It is rather the more jarring intrusion of apparently alien elements of Old Comedy such as low-status characters, transvestism, bathos, metatheatre and, less tangibly, humour, which could offer a parallel and precedent for the Senecan perversion of a noble idea of tragedy. It is well beyond the scope of this article to discuss how far fifth-century Attic tragedians either possessed or played with an idea of 'the tragic'. However, the possibility does provide a precedent and even conceivably a distant model for Seneca's practice. As with almost every aspect of Senecan tragedy, the salutary advice of Richard Tarrant must be kept in mind, and the largely unknown and unknowable ways in which fourth-century, Hellenistic, Republican and Augustan tragedians engaged with their generic status must be allowed to be at least as relevant for Seneca as the fifth century. ${ }^{122}$ Yet our main concern is not with influence but with parallels, and if the transvestism of Euripides' Pentheus could be felt as a troublingly comedic perversion of tragic norms, then a similar approach may be taken to Thyestes' belch. The key point that Attic paracomedy raises is how far we should read Seneca's satiric tragedy as paradigmatically tragic in its perversions, and how far as a uniquely extreme, if not unique, perversion of tragedy itself. Readers and audiences need not, of course, commit themselves to one view or the other, but the oscillation between the two is itself significant.

Two major-and, as ever, interrelated-ways in which Senecan tragedy is as perverted as satire are in their treatment of the corporeal and their jarring dissonances of tone. The satiric body has been the object of considerable study, notably in a 1998 special issue of Arethusa. ${ }^{123}$ Hooley sums up both its nature and its semiotic potential thus:

Satire centrestages the disfigured body: flawed, maimed, contorted, decaying. Let the body be seen in literature and its symbology ramifies, morphs. Decadent and decayed, it takes in everything from psychic implosion to the disintegrating 'bodies' of polity, culture and society. ${ }^{124}$

The Senecan tragic body is likewise disfigured, whether bloated, maimed, or dismembered, and always serving (also) as a symbol for the psyche, society, the

121. The classic study is Seidensticker (1982). See also Herington (1963); Seidensticker (1978); Scharffenberger (1996); Kirkpatrick and Dunn (2002); Foley (2008). Notes of caution are sounded by Gregory (1999-2000) and Wright (2005), 6-43.

122. Tarrant (1978).

123. See also Bramble (1974); Labate (1992); Gowers (1993), 109-219; Barchiesi and Cucchiarelli (2005); Freeman (2014).

124. Hooley (2007), 8. 


\section{ROBERT COWAN}

cosmos or the text. ${ }^{125}$ As Miller has crucially demonstrated, the satiric body is not that of the Bakhtinian carnivalesque, grotesque but fertile; its grotesqueness emblematizes confinement, sterility and death. ${ }^{126}$ As such, its resemblance to the Senecan tragic body is even closer. Both are equally distant from the noble, beautiful body of Aristotelian tragedy, and from the grotesque but generative body of Aristophanic comedy, where the absurdly padded belly and buttocks reflect the wholesome feasting at the play's end, and the ridiculous phallus the unproblematic sex which will follow. ${ }^{127}$

Thyestes, bloated with his own sons and belching, is close kin to Persius' Natta, drowning in his own layers of fat, the two of them grotesque in their very corporeality as corporeality, but even more so in what it symbolizes about their indiscriminate voracity and moral insensibility. ${ }^{128}$ The pulverized (non-) remains of the victims of a marble cart shedding its load are on a par with the unrecognizably mangled limbs of the dismembered Hippolytus, the destruction of the body constituting a negation of the very notion of selfhood, or the 'shapeless body' of Astyanax hurled from the tower, his identity obliterated and subsumed in that of his similarly disfigured father. ${ }^{129}$ The Oedipus of Phoenissae has come to a Cithaeron he associates not only with the general cycle of disaster attendant on all Theban royals, but more specifically with recurrent episodes of dismemberment, (dis)embodied in the figures of Actaeon, Dirce and Pentheus. ${ }^{130}$ There he symbolically dismembers himself:

125. On the Senecan tragic body, see esp. Segal (1986a); Most (1992); Pypłacz (2010), 75-91; Tondo (2010).

126. Miller (1998).

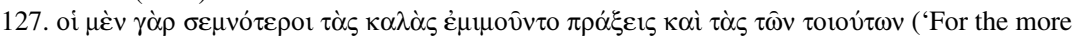
serious [poets] imitated beautiful actions and those of beautiful people', Arist. Po. 1448b25); tò

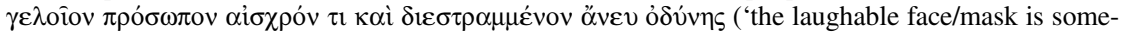
thing ugly and distorted without pain', 1449a36). On the male comic body, see esp. Varakis (2010) and Compton-Engle (2015), 16-58, both with further bibliography.

128. Segal (1986a), 334: 'In Thyestes' case the imagery of inward fullness, swollenness, turgidity shifts at the end from "breast" and "mind" ... to "entrails".' On the belch: Mader (2003). Natta: Pers. 3.31-34; 'Natta's sensory deprivation, alternately figured as a physical and psychological malady, is both his symptom and his disease.' Keane (2012), 93; cf. Gowers (1993), 185; Reckford (1998), 344.

129. quid superest de corporibus? quis membra, quis ossa / inuenit? obtritum uolgi perit omne cadauer / more animae ('What is left of the bodies? Who finds limbs, who bones? The whole body of the mob dies when it is crushed, like its soul.', Juv. 3.259-61). There is epic parody in the surrounding description of the collapsing marble and the soul by the Styx (Braund [1989b], 35; Powell [1999], 327f.), but not in the key description: 'agitated in manner, but simple and prosaic in style' (Powell [1999], 327). Hippolytus hic est? ... / complectere artus, quodque de nato est super, / miserande, maesto pectore incumbens, foue. ('Is this Hippolytus? ... Embrace his limbs, and caress what is left of your son, pitiable man, lying on him with mournful breast.' Sen. Pha. 1249, 1254f.), with Most (1992). NVN. iacet / deforme corpus. AN. sic quoque est similis patri. ('MeSSENGER: He lies a shapeless body. Andromache: In this way too he is like his father.' Sen. Tro. 1116f.), on which see also Schiesaro (2003), $199 \mathrm{f}$.

130. Phoen. 12-21. General cycle of disaster: Frank (1995a), ad loc. The following example of Ino implicitly rejects her usual deification but, despite the emphasis on the huge drop (uertice immenso 'from an immense peak', 22), focuses on the attempt to 'drown' (mersura, 25) Melicertes and herself, rather than smashing them on impact. On the associations of Cithaeron in Phoen.: Landolfi 


\section{BLOATED BUSKINS}

non destino unum uulneri nostro locum.

totus nocens sum: qua uoles, mortem exige.

effringe corpus, ${ }^{131}$ corque tot scelerum capax

euelle; totos uiscerum nuda sinus.

fractum incitatis ictibus guttur sonet;

laceraeue fixis unguibus uenae fluant.

aut dirige iras, quo soles: haec uulnera

rescissa multo sanguine ac tabe irriga.

hac extrahe animam, duram, inexpugnabilem.

(Sen. Phoen. 157-65)

I do not aim at one place for my wound.

In my entirety I am guilty: wherever you want, exact my death.

Break open my body, and the heart which could hold so many

crimes,

pluck it out; strip naked all the windings of my entrails.

Broken by rapid blows, let my throat make a noise;

or let my veins flow, torn by nails driven into them.

Or direct your rages where you usually do: these wounds,

tear them open again and water them with much blood and gore.

By this route drag out my soul, tough, siege-proof.

Oedipus paradoxically insists upon the wholeness and unity of his body and hence his self as a locus of guilt (totus nocens sum) and also as a unified, totalizing agent of retribution (toto impetu, / toto dolore, uiribus totis), but only as the prelude to performing a verbal self-sparagmos mimetic of the physical suicide he plans, reducing himself to his constituent parts, parts which are defined only by their function, to wound or be wounded. ${ }^{132}$ As Segal writes of Thyestes, the 'language of the body ... is disturbing because it reminds us of our physicality, of our inevitable reduction to being mere body. We are reduced to those primary bodily processes ... over which we have no conscious control'. ${ }^{133}$ This is the same dehumanizing process of objectification and dismemberment into constituent, functional parts which reduces aristocratic matronae and even Helen of Troy into a cunnus, Persius' heir to his cock and belly, the Graeculi to 'the guts of noble

(2012); on Actaeon in the play: Basile (2012); on characters' internal fracture more broadly: Mader (2010).

131. Most editors print Heinsius' conjecture pectus, which certainly has its attractions. Either word fits the current argument in different ways, corpus by emphasizing the initial, superficial unity of the body which is then fragmented, pectus by contributing one more fragment to the total.

132. See also Ginsberg in this volume on the symbolism of Jocasta's body in the play.

133. Segal (1986a), 334f. 


\section{ROBERT COWAN}

houses'. ${ }^{134}$ The decorum of wholeness which belongs to epic is perverted and mangled by both genres.

This indecorous mangling of the body in the text has, also in both genres, long been recognized as parallel to the mangling of the body of the text. ${ }^{135}$ 'Seneca rejects an aesthetic based on unity, arrangement, and anthropomorphic norms.' ${ }^{136}$ Both satire and Senecan tragedy thrive on incongruity, extreme shifts of tone, and generally the wilful violation of ideals of harmony and decorum. Just as 'mixture and misproportion have always been a vital part of satirical technique', so 'Senecan black humor derives much of its power through blurring fundamental distinctions or transgressing important boundaries-between life and death, human and animal, self and other... The combination of the ludicrous and the terrible heightens the sense of alienation conveyed by the drama.' ${ }^{137}$ The ways in which they do this are by no means identical, and Seneca's style, for example, maintains due tragic elevation of diction and has none of the jarring clashes of register so characteristic of satire. ${ }^{138}$ Clashes of tone, however, are a marked feature of both genres. The emphasis on the grotesque and the rejection of classicizing decorum in Senecan tragedy can be partially accounted for by situating them in a historical moment, one paralleled in contemporary literature in other genres and above all in art. ${ }^{139}$ Such an explanation can, however, only account for the popularity of such an aesthetic, and that only partially, not its nature or effects. We must also be wary of the Scylla and Charybdis of emphasizing incongruity at the expense of meaning, and of rejecting incongruity as a reaction to earlier dismissive assessments. Oedipus' famous or notorious self-injunction to be careful 'not to stumble into his mother' (ne in matrem incidas, Oed. 1051) is of course not a 'dreadful specimen of misplaced cleverness' or, with Pha. 1267 which 'rival[s]' it, a contender for 'arguably the worst line in Senecan drama'. ${ }^{140}$ But neither must we insist that the 'lines need not be played as "clever"... or bathetic, but as powerfully and deeply tragic'. ${ }^{141}$ The line, especially with its echo of Oedipus' reference in the prologue to how he 'stumbled into a kingdom' (in regnum incidi, 14), has profound thematic significance relating to chance and guilt, the hero's moral and

134. cunnus: Hor. S. 1.2.36, 1.3.107; Curran (1970), 225: 'woman is reduced to her sexual organs alone'; cf. Henderson (1989), 103-05. Pers. 6.71-74. uiscera magnarum domuum, Juv. 3.72: '[Juvenal's characters] are rendered as through a camera lens which focuses upon only the most essential elements and leaves it to the imagination of the viewer to reconstruct the whole. The emphasis on part over whole bears witness to the dislocation of values in the society.' Braund and Raschke (2002), 74.

135. Seneca: Most (1992). Satire: Bramble (1974); Gowers (1993), 109-219; Farrell (2007).

136. Staley (2010), 116.

137. Gowers (1993), 118; Meltzer (1988), $311 \mathrm{f}$.

138. On satire's clashes of register, esp. in Juvenal, see Powell (1999); Urech (1999); Schmitz (2000), 97-107.

139. Segal (1984); Varner (2000); Mader (2002b).

140. Tarrant (1985), 235; Coffey and Mayer (1990), 195.

141. Boyle (2011), 358 ad Oed. 1051, comparing it to Thy. $1046 f$. 


\section{BLOATED BUSKINS}

physical disabilities, and the fear of repeated incest, but it is still 'ironic and macabre', still unsettles the audience with an incongruity and confusion of emotional responses that is mimetic of the incongruity and confusion of categories in the incest at which it hints, still is designed to produce precisely the effect that it did on Tarrant, Coffey and Mayer, except that they did not give Seneca the credit to consider that it was deliberate. ${ }^{142}$ Seneca's tragic universe, like satire's dystopian city, is a world out of joint, a verkehrte Welt, as Lefèvre calls it, and the form of its representation is mimetic of their disorder and lack of harmony or decorum. ${ }^{143}$

Inevitably in a survey such as this, the emphasis has been on features which are common to all the tragedies rather than on differences between them, but each play must be considered as an entity in itself as well as part of the Senecan corpus. With this in mind, it must be acknowledged that some tragedies have a greater affinity with satire than others. Thyestes has a particularly close resemblance to satire, both in its almost unique emphasis on food and digestion, motifs generally avoided by high poetry, and in the wilfully jarring incongruities of tone which are partly troped by its treatment of this visceral subject-matter. ${ }^{144}$ Yet I hope that I have provided sufficient examples, and I suspect that most readers will recognize many others when refocusing on familiar passages through a satiric lens, that this almost paradoxical affinity with satire is a feature of all tragedy and one which Seneca consistently foregrounds and intensifies.

The more similarities and parallelisms we detect between the genres, and the closer Senecan tragedy (in practice) and satire (in theory and practice) grow, the stronger the resemblance between both and the satiric idea of tragedy also becomes. Despite satire's insistent distancing itself from tragedy and its construction of a polar opposite specifically for the purpose of self-definition through antithesis, the polarity contains the seeds of its own deconstruction. Or perhaps we might rather think of this assimilation as occurring, not despite the polarization, but because of the generic anxiety encoded in and dramatized by satire's act of protesting too much. This convergence is perhaps understandable enough in relation to passages such as Juvenal's adoption of a Sophoclean gape, quoted and discussed in section 1 above. If the satirist is, on one level at least, shifting

142. Quotation from Staley (2014), 112. See also Trinacty in this volume on the line's intertextuality with Callisto and Arcas at Ov. Met. 2.500.

143. Lefèvre (2002).

144. Gowers (1993), 22: 'Food...tends to be absent, except in its most solemn, sacred, and undefined terms, from the higher genres, Perhaps the most awkward exception to the rule is Seneca's Thyestes, where the moralist's obsessions spill over into tragedy, and the disguised limbs of the hero's infant sons take on the flavour of some contemporary evil stew. The hero's intestinal eruptions and thunderous belches are magnified on a cosmic scale, as though the disarray of the Roman tragic universe could best be brought to the surface by an explosion of unnatural food.' Littlewood (2004), 200: 'The association or deliberate confusion [in Thy. 1041-4] of stomach and womb, food and embryo is familiar. ... Satire and invective are the most productive genres for examples of this parallelism or confusion.' 


\section{ROBERT COWAN}

his satire towards (his idea of) tragedy, then it becomes almost banally circular to argue that his ideas of satire and of tragedy should bear a strong resemblance. Yet the parallels between satire and the satiric idea of tragedy, the ways in which satire willingly or unwillingly acknowledges the kinship of its ugly sister, are by no means limited to the so-called 'tragic satire' of Juvenal. Even when satire is most emphatically distancing itself from tragedy, the very act of protesting too much draws attention to their family resemblance. Horace's vain thirst for pure Callimachean streams and Persius' obsession with boiling satire down only make sense in relation to a recognition of its inherent bloatedness, confusion, monstrosity and perversion, the very features which it projects onto tragedy and which Seneca eagerly appropriates. In the attack on tragedy in his fifth satire, 'the list of negative qualities [in 5.11-13] ... in fact sums up many of Persius' own idiosyncrasies'. ${ }^{145}$ Our interest here, of course, is primarily in Senecan tragedy rather than satire, and in its sophisticated redeployment of these satiric moves. Its tendentious appropriation of the satiric idea of tragedy is one of the ways in which it moves closer to satire, accentuating further the two genres' innate affinity. Yet it does so, not only by appearing to agree with satire on this literary-critical question, but by embodying an idea of tragedy which satire, through layers of irony, denial and protesting too much, acknowledges to bear an uncanny resemblance to itself, its own ugly sister.

\section{Conclusion}

This reading of Senecan tragedy with, against and through satire is not—and is not intended to be-a master-key for interpretation. It complements and often supports, sometimes nuances, many existing interpretations which emphasize the tragedies' poetics of 'moreness', the relationship of the physical and the psychological, metapoetic and metatheatrical, Stoic and anti-Stoic readings and various others. I have deliberately omitted much reference to Seneca's prose writings, whose importance for the tragedies Mazzoli, Staley and others have demonstrated. This is not in any way to reject their significance, but rather because I am presenting a distinct and complementary approach. I have also made very little reference to issues of stagecraft and theatricality, an area whose importance is matched only by its controversy. My reasons here are that they do not interconnect with the issues under discussion in obvious ways, though there is room here for further work, especially on Seneca's engagement with satire's strong sense of its own theatricality.

To sum up, Senecan tragedy engages with verse satire and its close kin, skoptic epigram, in three interconnecting and indeed overlapping ways. The first is its appropriation of satire's essentializing, polemical construction of an 'idea' of

145. Gowers (1993), $186 f$. 


\section{BLOATED BUSKINS}

tragedy as overblown, excessive, transgressive, monstrous and swollen. This satiric idea of tragedy is fundamentally the mainstream classical idea of bad tragedy, and it is precisely that sense of perversion, of the failed sublime, of greatness gone awry which Seneca exploits. He uses the overblown, excessive, transgressive, monstrous passions and bodies, crimes and sufferings of his characters both to trope those generic qualities of 'essential tragedy' and to be troped by them. Form and content, each mimetic of the other, are characterized by a grotesque 'moreness'. Satire's assertion that tragedy is irrelevant to real life is the only part of the idea which Seneca rejects. The second is his incorporation in the tragedies of features which are demarcated as satiric-especially moralizing sections and those dealing with contemporary urban life-and remain self-consciously alien generic intrusions, similar to that of elegiac, epic or pastoral elements. Sometimes there is a degree of polemic, when a satiric moralizer such as Thyestes or Hippolytus is revealed to be self-deluded or bigoted, though in this Seneca is also imitating satire's own self-attack. Sometimes, the satiric mode is more clearly assimilated, or rather shown to work in tandem with more obviously tragic elements. This is one of Seneca's main responses to the satiric charge of tragic irrelevance and it shades almost imperceptibly into the third mode of engagement, whereby he takes the existing generic affinity between satire and tragedy, both genres of perversion, and accentuates it through an increased focus on bodily and poetic deformation. The increasing parallelism between satire and tragedy brings us full-circle as the same qualities of excess and deformation which link the two genres are also those which constitute the satiric idea of tragedy, an idea which, despite satire's self-conscious protests to the contrary, contains a large element of self-portrait.

The University of Sydney

bob.cowan@sydney.edu.au 